Portland State University

PDXScholar

8-12-1993

\title{
Child Care Support and the Reduction of Women's Stress and Role Conflict at the Work-Family Interface
}

Frances Marx Stehle

Portland State University

Follow this and additional works at: https://pdxscholar.library.pdx.edu/open_access_etds

Part of the Sociology Commons

Let us know how access to this document benefits you.

Recommended Citation

Stehle, Frances Marx, "Child Care Support and the Reduction of Women's Stress and Role Conflict at the Work-Family Interface" (1993). Dissertations and Theses. Paper 4749.

https://doi.org/10.15760/etd.6633

This Thesis is brought to you for free and open access. It has been accepted for inclusion in Dissertations and Theses by an authorized administrator of PDXScholar. Please contact us if we can make this document more accessible: pdxscholar@pdx.edu. 
AN ABSTRACT OF THE THESIS OF Frances Marx stehle for the Master of Science in Sociology presented August 12, 1993.

Title: Child Care Support and the Reduction of Women's Stress and Role Conflict at the Work-Family Interface

APPROVED BY THE MEMBERS OF THE THESIS COMMITTEE:

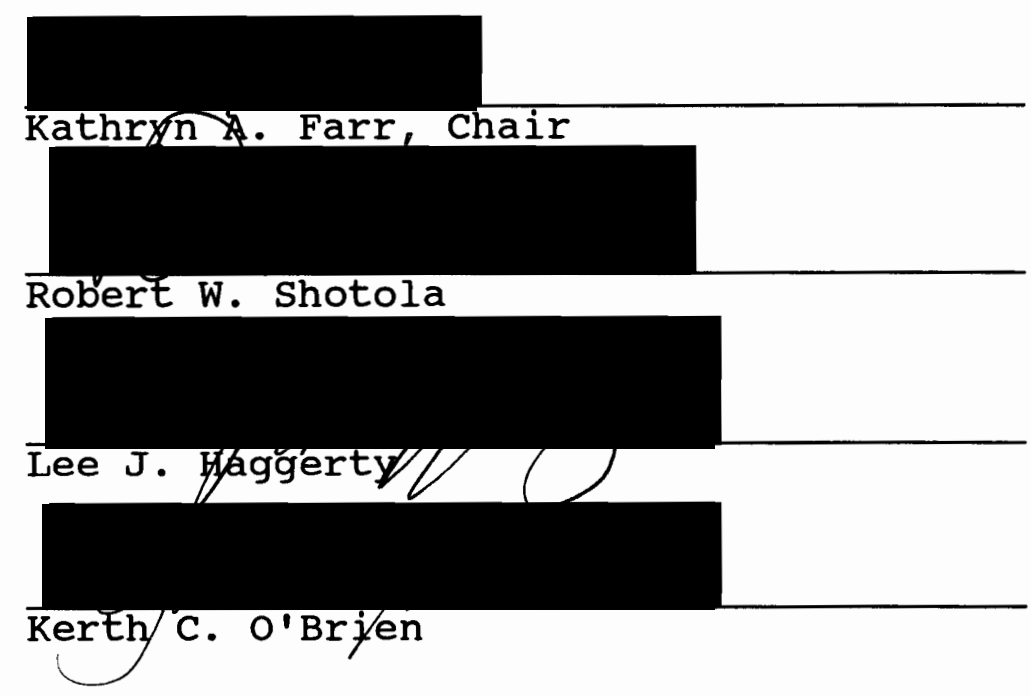

Working mothers may encounter difficulty combining work and family, particularly as this interface involves child care arrangements.

This research investigated the effects of various dimensions of child care support on stress and role conflict in employed mothers. It was hypothesized that as job support, affordability, spousal support, and satisfaction 
with child care increased, that child care stress, job stress, and role conflict would decrease.

The data were derived from a survey (Lane County Dependent Care Survey, Emlen, 1990) of women employed in 15 companies in the Lane County, oregon area. The study sample consisted of 825 full and part-time employed mothers with children under the age of eighteen living in the home.

This research analyzed the women's responses to questions pertaining to each of the four dimensions of child care support (four questions), and two questions on stress (one on child care stress and one on job stress) and one on role conflict. The questions were formatted into Likerttype scales, ranging from three to six points. Crosstabulations were calculated to examine eight hypotheses, four with stress as the dependent variable and four with role conflict as the dependent variable. Hypotheses with job support as the independent variable were supported with moderate positive correlations. Hypotheses involving spousal support were tested using only married women. The independent variable showed no statistically significant correlations with either stress or role conflict. Hypotheses involving affordability were supported by moderate positive correlations between low levels of affordability, and child care stress and role conflict. The last hypotheses used dissatisfaction with child care arrangements as the independent variable. These were 
supported by moderate correlations regarding child care stress and weak correlations regarding role conflict. Further directions in the examination of relationships between help with child care and the reduction of stress and role conflict for women are suggested. 
CHILD CARE SUPPORT AND THE REDUCTION OF WOMEN'S STRESS AND ROLE CONFLICT AT THE WORK-FAMILY INTERFACE

by

FRANCES MARX STEHLE

A thesis submitted in partial fulfillment of the requirements for the degree of

\author{
MASTER OF SCIENCE \\ in \\ SOCIOLOGY
}

Portland State University

1993 
TO THE OFFICE OF GRADUATE STUDIES:

The members of the committee approve the thesis of Frances Marx Stehle presented August 12, 1993.
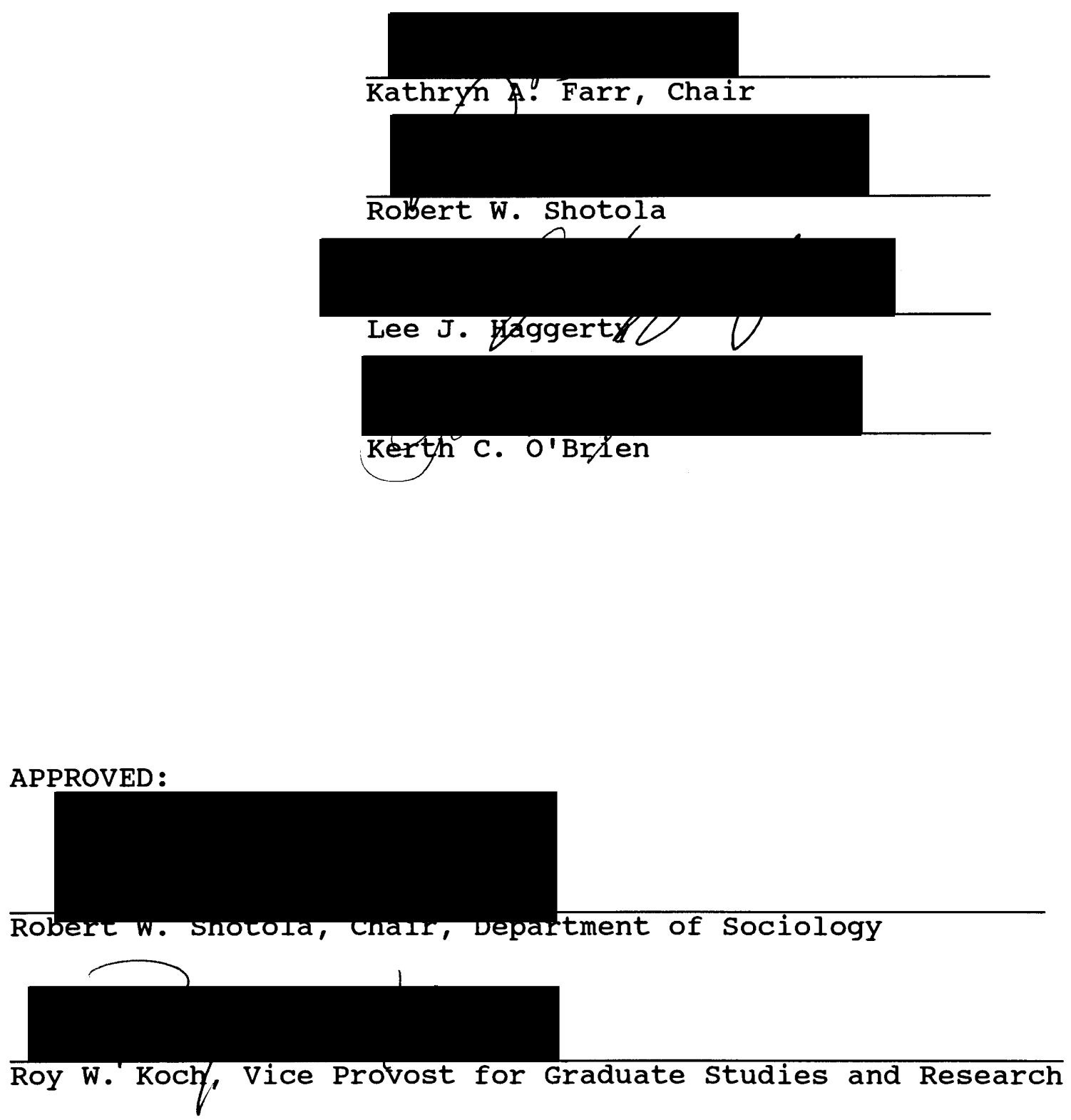


\section{ACKNOWLEDGEMENTS}

I would like to thank all of those who helped me with this thesis. Foremost, I would like to express my appreciation to my husband, Devon, for his support, and mention my daughter Alyssa, who makes this topic so personal. I also want to express special gratitude to Kathryn Farr, Ph.D., for her guidance and direction of this project. There are several people who assisted with the data analysis and interpretation. In particular, I want to mention Stephanie Limoncelli and Phillip Crawford. Lastly, Arthur Emlen, Ph.D. and Paul Koren, $\mathrm{Ph} . \mathrm{D}$. were instrumental in this thesis by allowing me to use the data that they collected. 
TABLE OF CONTENTS

PAGE

ACKNOWLEDGEMENTS $\ldots \ldots \ldots \ldots \ldots \ldots \ldots \ldots \ldots \ldots \ldots \ldots \ldots \ldots \ldots$

LIST OF TABLES.......................... vi

CHAPTER

I INTRODUCTION $\ldots \ldots \ldots \ldots \ldots \ldots \ldots \ldots \ldots \ldots \ldots$

II THEORETICAI FRAMEWORKS AND PRIOR RESEARCH .. 9

Role Theory....................... 9

Work-family Conflict............. 14

Feminist Work on Stress and Role Conflict 16

Child Care and stress............. 22

III METHODOLOGY ...................... 26

Hypotheses ...................... 28

Variables $\ldots \ldots \ldots \ldots \ldots \ldots \ldots \ldots \ldots . \ldots \ldots$

Job Support

Spousal Support

Affordability of Child Care

Satisfaction with Child-Care

Stress

Arrangements

Role Conflict

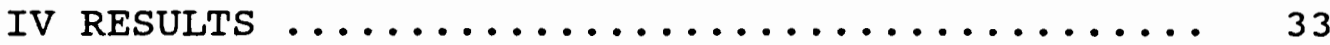

Findings on the hypotheses....... 37

Hypothesis 1

Hypothesis 2

Hypothesis 3

Hypothesis 4

Hypothesis 5 
Hypothesis 6
Hypothesis 7
Hypothesis 8

V

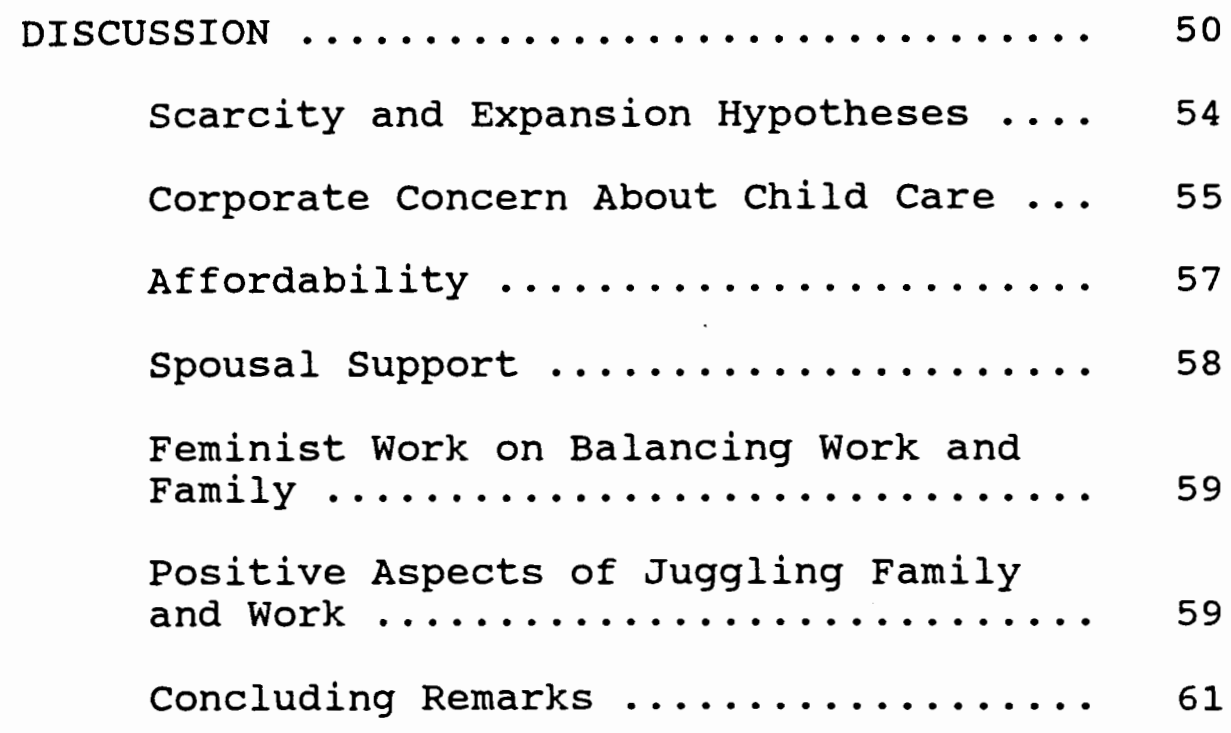

REFERENCES

63 


\section{LIST OF TABLES}

TABLE

PAGE

I Selected Demographics of Respondents, by

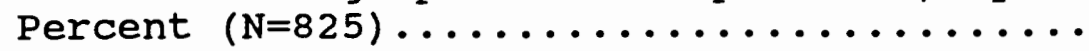

II Dependent Variable Frequencies, by

Percent $(\mathrm{N}=825) \ldots \ldots \ldots \ldots \ldots \ldots \ldots \ldots \ldots . \ldots \ldots$

III Independent Variable Frequencies, by

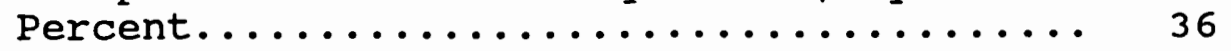

IV Job support and Child-care stress, by

Percent......................... 38

$\mathrm{V}$ Job support and Job Stress, by

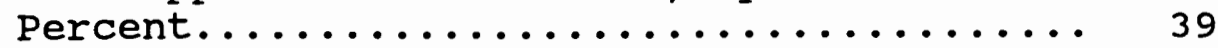

VI Job Support and Role Conflict, by

Percent....................... 40

VII Spousal support and Child-care Stress, by

Percent........................ 42

VIII Spousal support and Role conflict, by

Percent....................... 43

IX Affordability and Child-care stress, by

Percent........................ 44

X Affordability and Role conflict, by Percent 45

XI Dissatisfaction with Child-care Arrangements and Child-care Stress, by Percent........ 47

XII Dissatisfaction with Child-care Arrangements and Role Conflict, by Percent........... 48

XIII Significance of Relationships Between

Independent and Dependent Variables ...... 49 
CHAPTER I

\section{INTRODUCTION}

One of the most important recent developments in American families has been the dramatic increase in women's labor force participation. Women have always had worker roles, but presently more substantial proportions of women work away from the home and are getting paid for their labor. ${ }^{1}$ In the 1920's, gainful employment of women away from the home increased, then decreased during the Depression in the 1930's until the labor shortage of world War II. During the war large numbers of women went to work, taking jobs previously filled by men. After the war, men and women revised the traditional roles so they were less restrictive. Many women maintained their employment, partly for financial reasons. The increasing affluence of the 1950's brought back the more traditional roles, with women's emphasis on staying close to home and caring for the children, and men's focus on their breadwinning responsibilities. Filine (1974) points out though, that the young adult generation of the $1960^{\prime}$ 's openly defied these

1. It should be noted that women of color and working class women have always worked in the United States. The change is primarily among white middle class women (stromberg and Harkess, 1988). 
restrictive polarized roles and helped to stimulate the women's movement of the 1970's. Scholars and writers touted the idea that women could participate in the family and work worlds simultaneously ( see for example, Friedan, 1963). But Ellen Galinsky, researcher and child advocate, has noted the presence of reservations regarding the compatibility of motherhood and employment. In one survey (Galinsky, 1986), three quarters of the staff of an "excellent" child-care center thought that "it would be better for young children if their mothers didn't work." In another survey (Galinsky, 1986), 42 percent of employed mothers of children under the age of twelve endorsed the sentiment that "having a mother who works is bad for children under six." In a study by Hock and associates (1984), this same ambivalence is present. Even though two-thirds of the mothers planned to return to their jobs before the child's first birthday, nearly all of them subscribed to traditional attitudes about exclusive mother care for babies. This kind of thinking suggests that women still tend to think of their paid work as "secondary" or "extra."

The upheaval in the work-family gender role system over the past two decades has caused men and women to question their preference for, and reliance on, the traditional nuclear family. The proportion of women in the work force has certainly increased, with many of these women in childbearing years. In fact, in 1976, 11 percent of infants 
under one year of age had mothers in the work force. By 1988, this figure had climbed to 51 percent (U.S. Bureau of the Census, 1989). Women's greater involvement in the labor market requires reconsideration of the specialized roles of the instrumental breadwinner father and the nurturant homebased mother. There may be new stresses as women, men and couples attempt to describe and accept new role definitions. society has made it difficult for women to combine domesticity and participation in the paid labor force. The incompatibility of domesticity and career, argued coser and Rokoff (1971), was more the product of cultural convention than the inevitable consequence of biology. They noted that men systematically exclude married women from professional work on the ground that no one could simultaneously sustain a full commitment to an occupational organization and to family management. The question coser and Rokoff posed was "Who is the no one?." The employed man is routinely expected also to be a "family man," although it is generally understood that this role is secondary to the worker role in terms of actual participation. The claim is made, they point out, that a person's deep commitment to any organization as evidenced by having prestige, being visible, and being relatively irreplaceable - is jeopardized if he or she is committed to another organization as well. It might be that the type of organization that is diverting the person's attention and energy is important. Coser and Rokoff observe 
that the same behavior is rewarded if it is perceived as reflecting commitment to the profession, but labelled problematic if it reflects commitment to family. They provide an example of "an academic department that might disapprove of a woman who cancels classes to attend to her family but applaud a male professor who cancels classes to present a paper at a meeting or to manage the affairs of some organization of which he is an officer " (Coser and Rokoff, 1971) .

The aim of this study is to explore aspects of stress and role conflict in working women's lives. In particular, this thesis examines the effects of various dimensions of child-care support, emphasizing contributions by the employer, on stress and role conflict. In looking at these relationships, attention will also be paid to the kinds of child care women use and the availability of safe and reliable care. A review of the literature includes several researchers' analyses of role conflict and stress, particularly as they relate to women balancing work and family. Research on the work-family interface tends to focus on two areas: feminist studies that address issues of inequality and structural antinatalism, and studies done for corporations to investigate the relationship between familyfriendly policies such as child care (parental leave, subsidized care, on-site care) and flex-time and other such policies, and employee productivity and retention. 
Researchers have begun to define and examine a concept called "work-family conflict" (e.g. Friedman, 1991), the topic of this study. Although for some people, work and family remain independent of each other, many experience some form of conflict between these two spheres. One study (Friedman, 1991) reported that in five out of eight companies studied, about 50 percent of employees reported some work-family conflict.

Various sources of work-family stress have been identified. The amount of time an individual spends on the job and at home can cause distress. Burden and Googins (1987) found that married mothers spend about 85 hours per week on work and family responsibilities, while married fathers spend 66 hours per week on them. In this same study, work-family role strain was found to be the most important factor associated with measures of decreased well-being such as depression, decreased health and energy, lower life satisfaction, and decreased job satisfaction.

Over several years, sociologist Arlie Hochschild (1989) interviewed in depth fifty dual-earner couples with children who lived in the San Francisco area. Hochschild characterized the women as exhausted, and found that, no matter what their social class or ethnic group, working mothers put in a second shift of work at home. The hours that women put in during the second shift would amount to an extra month of work each year. 
With the high percentage of employed mothers it is especially important for both parents and employers to address this "conflict". One study (Repetti, 1987) focused on employees of a bank and examined relationships between the social environment at work, individual psychological well-being, and family life. Repetti combined quantitative methods and qualitative interviews with bank employees and found that if occupational stressors continue on a daily basis, employees may become preoccupied with their workrelated problems and needs. She speculated that "their ability to be responsive to the feelings and needs of a child or a spouse may be diminished as a result" (p.120). Their perceived stress could leave them less able to cope effectively with problems at home and "they may become more withdrawn, less empathic, and less effective and reliable family members" (p.121).

Coser (1974) stated that the difficulty experienced by professional women derives from participation in different activity systems whose claim on time allocations are incompatible; moreover, the values underlying these demands are contradictory. Working women, especially professional women, are expected to be committed to their work, but they are also required to give priority to their families. To complicate this juggling act further, research reveals that, in general, women are responsible for making the child-care arrangements (Phillips, 1989). If a mother consistently 
finds herself caught between being a productive full-time worker and shouldering all of the family/household responsibilities, she's likely to feel conflicted about her dual roles. If a mother has to work or chooses to work, and her spouse, employer, and extended family are unable or are unwilling to help, this mother, by default, has two fulltime jobs that will compete for her attention and time. Goode (1960) states that an individual can choose a less conflicting set of roles to reduce stress. This may be an option for some, but as he also points out, an individual needs to be able to choose a less conflicting set of roles; many lower status occupations do not offer that flexibility. Many women don't have these choices, as they are working out of financial need, and most bear the sole responsibility in arranging for child care (Phillips, 1989).

Given these patterns of behavior in our society, mothers may wonder about whether or not the "ideal" nuclear family can fulfill all of their needs anymore. They may also wonder whether their private welfare is inextricably tied to policies and actions within society as a whole. The traditional family, with the husband as the breadwinner and the wife primarily responsible for caring for the family, may no longer be a viable option for many people in the United states. Family life can only remain vital to the extent that the institutions that shape private lives are made more responsive and accountable to families' actual 
needs. 


\section{CHAPTER II}

\section{THEORETICAL FRAMEWORKS AND PRIOR RESEARCH}

\section{ROLE THEORY}

Role strain, role conflict and role overload are sometimes used interchangeably in the literature when, in fact, they are related but distinct concepts. Goode's perspective on role strain (1960) has been used in this study to operationalize the perceived stress that women identify based on their difficulty in fulfilling role obligations. While role strain is most typically referred to as tension within a single role, he defines it as, simply, the difficulty in meeting given role demands. He notes that all individuals take part in many different role relationships and there may be contradictory performances required or conflicts of time, place or resources. He states that if a person conforms fully in one role, fulfillment will be difficult in another. Role overload is commonly defined as having too many role demands and too little time to fulfill them (Baruch et al. 1985).

Role conflict is said to exist when persons simultaneously fulfill multiple roles, such as spouse, parent, and paid worker and experience conflicts between the 
roles. Kahn, Wolfe, Quinn, Snoek, and Rosenthal (1964) define role conflict as the "simultaneous occurrence of two or more sets of pressures such that compliance with one would make more difficult compliance with the other." Kopelman, Greenhaus, and Connolly (1983, p. 201) similarly define role conflict as the "extent to which a person experiences pressures within one role that are incompatible with pressures that arise within another role." According to Coverman (1989, p. 968), "role overload leads to role conflict only when the demands of one of the multiple roles make it difficult to fulfill the demands of another role." Among women, this is more likely to occur when no alternatives exist to help them fulfill their various roles adequately. Coverman illustrates this by comparing an employed mother in a society with few alternative childcare arrangements to an employed mother in a society that provides adequate child care. The mother without the support will be more likely to experience role conflict.

One of the earliest frameworks for the examination of family stress is the ABCX model developed by Hill and advanced by Mccubbin and Patterson (1983) as the Double ABC$X$ model. The model states that $A$ (the stressor event) interacting with $B$ (the family's ability to cope with a crisis, their "crisis-meeting resources"), interacting with $C$ (the family's appraisal of the event) produces $X$ (the crisis). Lack of child care might be a stressor event, for 
example.

stressors and hardships call for family coping and management skills. When family members do not have adequate resources for coping and managing- either because of prior strains or because of the character of the stressor event itself - stress emerges. It is a response of the family to the changes and tensions brought about by stressor events. Crisis occurs when family disorganization ensues from a situation of inadequate resources. The Double ABC-X model added the component of "pile-up" to account for the fact that the stress process occurs over time and is responsive to changes in resources and demands (La Vee, Mccubbin, and Patterson, 1985). This may lead to a question of how certain kinds of support might change the person's appraisal of the stressor event or the stressor event itself. If a mother has her child in sub-standard child-care because that's all she can afford, she could identify this as a stressor. If her employer offers her a subsidy for child care so she can then move her child to a safer child-care situation, this may no longer be a stressor for her and she might also believe that her ability to cope has increased because of the increase in resources or support.

Two major hypotheses about the relationship of role occupancy to stress focus on role accumulation, that is, the number of roles that an individual occupies. The first formulation, eventually labelled the scarcity hypothesis by 
Marks (1977), was put forth by Goode (1960), and extended by Coser (1974), slater (1963) and others. This formulation rests on two premises: a) that individuals have a limited amount of energy and b) that social organizations are greedy, demanding all of an individual's allegiance. According to this model, people do not have enough energy to fulfill their role obligations; thus compromises are required. Therefore, the more roles one accumulates, the greater the probability of exhausting one's supply of time and energy and of confronting conflicting obligations, leading to role strain and psychological distress.

The expansion hypothesis ( also called the enhancement hypothesis) challenged the scarcity hypothesis and focused on the net positive gains (such as status and money) to be had from multiple roles (Marks, 1977; Sieber, 1974). Researchers from several disciplines support this view that emphasizes the privileges (e.g., flexibility on the job, more room for creativity on the job) rather than the obligations that accrue to role incumbents (Crosby, 1984; Epstein, 1983; Thoits, 1983). Critical to this hypothesis is the ability to trade off or bargain the disliked aspects of some of the roles. An example might be a busy executive who has other people taking care of laundry, buying birthday presents, transporting children, and so forth. Long and Porter (1984) point out, though, that this may not fit for women, whose roles often lack the status and 
norms that permit this bargaining.

According to crosby (1987) role combination is a given. She states that even the homeless, who are typically regarded as the most marginal of society's members, engage in multiple roles with peers, with the general public, and with agents of social control. Researchers have recently been paying more attention, not to the number of roles, as all of us have more than one role, but to the kinds of roles that are combined. certain status/role combinations tend to be defined as problematic and are perceived to encompass competing and/or contradictory commitments (Crosby 1987).

A major gap in both approaches is that neither hypothesis specifically differentiates among various social roles, for example, paid worker, wife and mother (Barnett and Baruch, 1985). Specifically, for women, the role combination of paid worker and wife may differ from that of wife and mother in the patterning of privileges and obligations. Traditionally, women's roles, whether in paid employment or as wife or mother, tend to have low social value, with more obligations and fewer privileges. Thus, these role combinations may not fit into theories of multiple roles which assume increased privileges with increased number of roles, as commonly found in the workplace. Additionally, some researchers (Nye and Hoffman, 1963) believe that the employee role is basically masculine and that the woman who is employed outside the home is 
placed in the impossible position of playing masculine roles during the day and a feminine role in the evening. They believe that the behaviors required in the workplace -aggressiveness, rationality, and competitiveness-- are incompatible with the requirements that mothers be accepting, nurturing, and accommodating (Nye and Hoffman, 1974). Traditionally, however, men's roles in the workplace and the family occur simultaneously. Their contribution through their work is often seen as their contribution to the family.

\section{WORK-FAMILY CONFLICT}

A number of researchers have observed that the demands on white-collar workers for travel, long hours, and family relocation, no less than the shift work and routineness of many blue-collar jobs, can be emotionally draining (Kanter, 1977; Komarovsky, 1962; Pahl and Pahl, 1971; Piotrowski, 1979; Renshaw, 1976; Rubin, 1976). Today, studies designed as simple comparisons of male-breadwinner versus dual earner families yield no notable differences in mother-child relations or marital quality ( Mischel and Fuhr, 1992). Results of recent studies using more complex designs have been more informative. Researchers who consider occupational conditions find that the more satisfied mothers are with their jobs, the better relations they have with their children (Harrell and Ridley, 1975; Piotrowski and Katz, 
1983). Others have found greater marital satisfaction associated with positive job mood and low levels of job tension (Piotrowski and Crits-Christoph, 1981).

Scanzoni (1978) suggests that as the meaning of work changes for women, so will the way in which women negotiate family conflict with husbands. A change in the meaning of work for women will influence marital roles, bargaining, power and conflict.

Keith and Schafer (1980), in a study on role strain and depression, found women in two-job families experienced significantly more work/family role strain than did the men in these families, and that woman were significantly more depressed than men.

As part of a report on work-family issues, Friedman (1991) has identified sources of work-family conflict as divided in the following way:

Jobs contribute to work-family conflict when the employee:

* works long hours;

* has a burdensome work schedule involving overtime, week-end work, travel demands, or shift work;

* has little control over the hours worked;

* has a job with little autonomy;

* is very absorbed in the job;

* has no job security;

* has changed jobs due to promotion, layoff or relocation;

* has a very physically or mentally demanding job;

* has a negative social climate at work;

* has unsupportive co-workers;

* has an insensitive supervisor;

* is in a company with inflexible work policies. 
Families contribute to work-family conflict when the employee:

* has a disapproving spouse;

* has inequities in the marriage;

* has an unequal division of home labor;

* has children, especially preschoolers;

* has had unstable child-care arrangements;

* has elder care responsibilities, especially for relatives living at a distance.

Identifying the factors associated with work-family conflict and studying means of reducing this conflict may improve womens' health as well as improve their attitudes about work.

FEMINIST WORK ON STRESS AND ROLE CONFLICT

Some research focuses on inequality and discrimination against women. According to coser (1974), in the segregationist approach to the study of work and family, each role is seen as "greedy for time", and as requiring drastically different, even mutually exclusive, value systems and capabilities of its participants. This has led to barriers interfering with women's participation in paid work. Coser points out that people are expected to play, and do play, multiple roles. That is not the problem; the problem is when one or more roles demands totalistic claims on time. This occurs with "greedy institutions", who want to extinguish competing institutions, such as the family. Coser (1974, p.5) provides the example of the Catholic church, which requires celibacy of their priests to "minimize the divisive pull of family obligations." Following this logic 
then, the individual may eventually find herself restricted to and dependent on the one institution that houses her identity, as the other competing institutions or role-sets relinquish their claim on her time. Coser defines the modern family as a "greedy institution", to which the female is expected to devote her time and attention. Coser states that women's higher emotional investment in family life than in career life contributes to the disproportionately low number of women in high status occupations. He states, "Their exclusive attachment to the family, moreover, and the sacrifices they make in its service, binds them more securely to it" (1974, p. 91). The more time, energy and emotions the women invest in their family, the more tied they become to it, while their husbands become freer to invest in their occupations. Coser uses the concept of cognitive dissonance to illustrate this further. "Since it is very difficult to repudiate objects in which one has invested so much, the more one invests in the object, the greater the hold that object has on the person" (1974 p.91). Again, the more women carry out their "roles" as traditionally defined, and devote themselves to caring for their family, the more they are going to feel compelled to keep doing so. The conflict for a woman occurs when she wants to share her time and energy with both her family and her career. For many women, the time "conflict" is only one aspect. Our culture still mandates that women give 
priorities to their families regardless of their occupation, but the employer, also representing a greedy institution expects them to be committed to their work. Historically, this has not been a problem for men (although this may be becoming less true; see Hochschild, 1989) because men have been assigned the "powerful" role of breadwinner. At least since prior to industrialization and urbanization (Stromberg and Harkess, 1988), men have been the providers and women have been provided for. Now that both are providing for the family financially in many cases, the greedy institutions have to re-evaluate their claim on time. Because the family is a smaller unit, it seems to adapt to change. Employers are realizing that they, too, can adapt and assist families in meeting the demands of their multiple roles.

As mentioned in the introduction, Arlie Hochschild studied the problems of women combining work and family from the aspect of the greater amount of time and energy that women spend on caring for the family, in addition to a job, than men do (1989). She studied more than fifty couples and took particular interest in how the "ideal" of marriage differed among these couples. A split between the traditional and the egalitarian ideals occurred between social classes in that the working class tended toward the traditional ideal (as did men overall). The middle class tended toward the egalitarian ideal (as did women overall). The stress these couples felt crosses lines of social class 
in different ways. The working class often lacked the money to pay for services and quality day care, and faced economic insecurity as well as undesirable job conditions. The uppermidale class are affected by the instability of the help for which they are paying and the enormous amount of time their careers require. Hochschild's study demonstrated that husbands and wives have "gender strategies", which can determine how the couples deal with the second shift. If, for example, a husband believes that housework is women's work, but has a wife with an egalitarian ideal, he may actually help with the second shift more than a husband who believes in the man's responsibility to help with caring for the family, but is married to someone who takes all that responsibility on herself. These gender strategies can make appearances deceiving.

Some women whom Hochschild interviewed tried direct approaches to get their husbands to "help them more" 2 ; others tried non-direct approaches such as feigning illness, playing helpless at cooking, etc. Others even withheld sex out of anger and frustration. Some women, who didn't want to "impose" on their husbands, began "supermoming," absorbing themselves in the worlds of both family and work. Additional strategies to alleviate the stress of the second shift were

2. It should be noted that some of the women in Hochschild's interviews described their husband's help in a manner which suggests that he was helping her with "her" work, reflecting the stereotype that domestic work is a woman's responsibility. 
to cut hours at work, cut back time on housework, marriage, self and child. Hochschild's study revealed that one out of five men in the study were as actively involved in the home as their wives. Among those who weren't, some cited an unsupportive workplace as one of the reasons they didn't spend as much time with their family. According to Hochschild, "Many men feared that their doing anything for family reasons- moving to another city, missing the office party, passing up a promotion- would be taken as a sign they lacked ambition or manliness" (1989 p. 218).

other research does show that some men are spending a bit more time caring for house and children than before. One study of families with children (Couter et al., 1987) found that the men in dual-earner families spent significantly more time than other men taking care of their children. More specifically, the men in dual-earner families performed twice as many child-care tasks on their own (without the wife present) than the men in single earner families. Some feminists attempt to bridge the perceived conflict of interests between feminism and motherhood, particularly when it comes to child care. Skold (1992) points out that this perception of a conflict of interest is the product of two basic assumptions:

First, it is assumed to be in the interests of children to be cared for within their families, primarily by the mother, until they are ready for school. From this perspective, any form of substitute care is less desirable and possibly 
damaging to the child. The second assumption is they must participate in work and gality with men, the same way men do, that is with public life in accommodation to the demands with little 114)

So, if these assumptions are accepted, children become a barrier to women's equal participation in the work force, and women are faced with choosing between their own economic and personal interests and their children's well-being. Feminists typically advocate for women's full participation in all aspects of society, and don't see children as a constraint. Feminist thought advocates not only the integration of women into the public sphere, but also a transformation of the public sphere, so that neither women nor men must sacrifice family involvement for participation in the larger society (Hoffman, 1985). It seems plausible that conflicts between feminism and motherhood result from the way in which work and family life are structured in our society, a structure that was established when women's roles were primarily as caretakers. With this in mind, changes in the structure of work and family, some of which have already begun to appear, could reduce the strains of a situation where children are seen as barriers to women's equality. Skold (1992) points out that the radical separation of work and family life that now seems normal stands in contrast to pre-industrial time when the family was an economic unit, with members working together. The notion that the role 
systems of family work (see Pleck, 1985) entail contradictory commitments partialiy resulted from the traditional and separate roles established during the Industrial Revolution. Women occupied primarily the household management and childcare roles. Now, women are in the labor force in great numbers, but child care is still defined as the responsibility of individual women, and neither men, nor society as a whole, take responsibility for raising the next generation. It is typically mothers who locate child care, stay home or make alternative arrangements when the children are sick, and coordinate the logistics of transportation and schedules (Hochschild, 1989). In other words, mothers are the child-care managers.

\section{CHILD CARE AND STRESS}

It is extremely difficult to get an accurate picture of child care in America because there is no systematic collection of data at the national level. Hewlett says that even so, "experts in the field agree that hundreds of thousands of preschool children spend the working day in poor-quality, even dangerous, care, and as many as 10 million schoolchildren aged six through thirteen are without adult supervision for several hours each day" (Hewlett, 1991 p.63).

Cattan (1991) suggests that much of the research on child care has focused on women in the labor force. He 
analyzed data from the National Longitudinal survey of Youth and concluded that the lack of affordable, quality child care was the reason an estimated 1.1 million young mothers (between the ages of 21 and 29) did not seek or hold a job in 1986. These women represented almost 14 percent of the total population of mothers 21 to 29 years old and accounted for 23 percent of those who were out of the labor force in that year.

Much of the research specific to child care and stress on the family has been carried out by researchers on behalf of corporations and policy-making groups. While a sizable portion of the research on child-care focuses on the effects of maternal employment on the children, little attention is given to the effects of employment on working mothers. Bohen and Viveros-Long (1981) surveyed flexitime benefits in government agencies, using job-family role strain as a dependent variable. They found that for people without primary child-care responsibility, more control over their time made a significant difference in role stress. However, for employed parents with employed spouses, flexitime made little difference in the degree of job-family role stress. According to the study, the time and energy demands of dual-worker families are not dramatically altered by minor changes in daily work schedules. They concluded that flexitime itself does not necessarily reduce job-family role stress for working parents. In the same study, the 
researchers did find lower role strain among working couples who strive for equity in allocation of family tasks, including child care, than those who do not.

Emlen and Koren (1984) showed that, like absenteeism, stress was related to how families arranged and managed their child care. Exactly half of employed mothers who relied on their children under 12 to care for themselves reported stress related to child care. Additionally, child care as a source of stress for employees was not significantly different at any level of family income (Emlen and Koren, 1984). Six studies (see Friedman, 1991) surveyed the users of employer-supported child-care centers. Although in two of the surveys high morale was found to be the most likely benefit resulting from use of the center, most employees believed that their absenteeism declined, and that their productivity improved because of the child-care center. In summary, research in this area suggests that family-friendly programs do help reduce stress for employees and perhaps have even improved productivity, thereby benefitting the company.

Because there has been concern from so many perspectives on work-family conflict, both as a feminist issue and as an employment issue, an analysis of these issues would be useful. Research in this area, so far, has either examined child-care supports as they benefit the child or the company. Other research has investigated the 
role of workplace supports for women, such as flex-time or fringe benefits, on reducing their stress, or on individual stress-reduction techniques, such as time management. This thesis attempts to tie these areas together by exploring how workplace child-care supports may help women cope with managing their job and complicated child-care arrangements. It is important to look at this not only from a policy perspective, but also from a feminist perspective that examines the inequalities present in many societal institutions. 
CHAPTER III

\section{METHODOLOGY}

Data for the present study came from the Lane county Dependent Care Survey, conducted by Arthur Emlen and Associates, Inc., in cooperation with the Regional Research Institute for Human Services, Portland state University. In February 1990, the survey was distributed to 15 Lane county, oregon companies and agencies. Emlen (1990) reported the following findings. Out of 6352 employees who were surveyed, 3295 (approximately half of whom were women) responded. Return rates ranged from $25 \%$ to $100 \%$, with a median return rate of $71 \%$ for participating organizations and an overall return rate of $52 \%$. Employee residences were distributed geographically across many Lane county communities, although heavily concentrated in the Eugene and springfield area. Sample sizes were sufficient to compare seven zip codes, east county and west county.

The survey was conducted initially for the purpose of assessing the nature and extent of child and adult care needs of employees, with special attention to the relationship of job requirements to family characteristics and to community differences in dependent care needs. The survey had 65 questions, ranging from demographic questions 
such as age, sex, occupation, income, number of children, and questions about the job, to specific questions about child-care arrangements, adult dependent care arrangements, satisfaction with those arrangements, and perceptions of workplace stress as it relates to child and adult dependent care.

The focus of the present study was on various dimensions of child-care support on working mothers' level of stress and role conflict. The independent variables were four components of child-care support: job support, affordability of child care, spousal help with child care, and overall satisfaction with child-care arrangements. The dependent variables were stress and role conflict. study subjects were full-time and part-time employed mothers with children under age 18. Mothers comprised $56 \%$ of the total sample of 825 respondents; $52 \%$ of this subsample worked full-time. The respondents were recruited through a task force of county and company representatives. A needs assessment was conducted by the researcher (EmIen, 1990) and the task force then recruited companies. The companies then provided advance notice to all employees, which included a letter of support from the Chief Executive officers of each company, and the survey was distributed to all employees. The respondents mailed the completed surveys directly to the researcher in a sealed envelope. The survey was approved by Portland State University Human Subjects Committee prior to 
being administered.

Hypotheses are Iisted below.

\section{HYPOTHESES}

1) As job support increases, stress will decrease.

2) As job support increases, role conflict will decrease.

3) As spousal or domestic help increases, stress will decrease.

4) As spousal participation increases, role conflict will decrease.

5) As affordability of child care increases, stress will decrease.

6) As affordability of child care increases, role conflict will decrease.

7) As satisfaction with child-care arrangements increases, stress will decrease.

8) As satisfaction with child-care arrangements increases, role conflict will decrease.

Data were analyzed with frequencies and crosstabulations.

\section{VARIABLES}

The following questions were used to measure the independent variables.

Job support

The survey asked, "To what extent do the management 
practices in your department, branch, or office make it easy or difficult for you to deal with child-care problems during work hours?
1) Very easy
2) Easy
3) Somewhat easy
4) Somewhat difficult
5) Difficult
6) Very difficult"

\section{Spousal support}

The survey asked, "In your family, who takes responsibility for child-care arrangements?
1) I do completely
2) Mostly I do
3) Equally shared with spouse or other"

\section{Affordability of child care}

The survey asked, "How easy or difficult has it been to pay for child-care arrangements?
1) Very easy
2) Easy
3) Somewhat easy
4) Somewhat difficult
5) Difficult
6) Very difficult" 
Satisfaction with child-care arrangements

The survey asked, "What things do you dislike (if any) about your current child-care arrangements. Check all that apply.

1. I don't dislike anything

2. Too far from home

3. Cost too high

4. Don't like program

5. Don't like caregiver

6. Too many kids

7. Worried about safety

8. Too dirty or unsanitary

9. Other: ."

Respondents who checked that they don't dislike anything were excluded from the crosstabulation. Those who checked "other" were also excluded. The number of items checked was totalled, resulting in a scale that increased as the number of dissatisfactions with the arrangements increased.

The following questions were used to measure the dependent variables.

\section{stress}

The survey asked, "We would like to know which areas of life are creating difficulty, worry, or stress for people. In the past four weeks, to what extent have the following 
areas been a source of stress to you?
a. Child care
b. Your job."

For each of these, the respondent rated the item in the following manner:

0. Not applicable

1. No stress at all

2. Hardly any stress

3. Some stress

4. A lot of stress.

\section{Role conflict}

The survey asked, "Circumstances differ and some people find it easier than others to combine working with family responsibilities. In general, how easy or difficult is it for you?
1. Very easy
2. Easy
3. Somewhat easy
4. Somewhat difficult
5. Difficult
6. Very difficult."

This question was chosen because it asks for the respondents' perceptions of how well they feel they are juggling work and family responsibilities, which is 
consistent with other research that measures role conflict in subjective terms (Barnett and Baruch, 1985). As discussed earlier, it is not so much the occupancy of multiple roles that is necessarily important, but the pressures within those roles that may lead to conflict in fulfilling the role obligations. 


\section{CHAPTER IV}

\section{RESULTS}

Descriptive statistics portray the circumstances of this sample of women. Table I shows that the mean age of the women was 37 , and that most of the women were married with their spouses working full-time. Most of the women had children under age 12 and most of them had middle-range household incomes. Just over half of the women worked fulltime, with the highest percentage of jobs concentrated in the professional/technical, registered nurse, and clerical categories.

\section{TABLE I}

SELECTED DEMOGRAPHICS OF RESPONDENTS, BY PERCENT

$$
(N=825)
$$

Mean age

Family status:

\%ingle

: spouse employed-full

$\%$ spouse employed-part

$\%$ spouse not employed

\section{7}

Household composition:

$\begin{array}{lr}\% \text { with child }<3 \text { yrs } & 21 \% \\ \% \text { with child }<6 \text { yrs } & 43 \% \\ \% \text { with child }<9 \text { yrs } & 59 \% \\ \% \text { with child }<12 \text { yrs } & 74 \% \\ \% \text { with child }<18 \text { yrs } & 100 \%\end{array}$


TABLE I

SELECTED DEMOGRAPHICS OF RESPONDENTS, BY PERCENT (continued)

Household income:

$\begin{array}{lr}\%<\$ 10,000 & 2 \% \\ \% 10,000-19,999 & 9 \% \\ \% 20,000-29,999 & 20 \% \\ \% 30,000-39,999 & 21 \% \\ \% 40,000-49,999 & 18 \% \\ \% 50,000-59,999 & 14 \% \\ \% 60,000 \text { and over } & 15 \%\end{array}$

Time with employer:

$\begin{array}{lr}\%<1 \text { year } & 6 \% \\ \% 1-5 \text { years } & 48 \% \\ \% 6-10 \text { years } & 25 \% \\ \% 11-20 \text { years } & 20 \% \\ \% 21 \text { and more years } & 1 \%\end{array}$

Occupation:

$\%$ professional/tech. $19 \%$

$\%$ managerial/admin. $\quad 7 \%$

$\%$ registered nurse $27 \%$

$\%$ I.P.N. / aide 5\%

$\%$ sales $1 \%$

\% clerical $21 \%$

$\%$ mail carrier $3 \%$

$\%$ mail clerk $3 \%$

$\%$ service $3 \%$

$\%$ transport operator $\quad 1 \%$

$\%$ warehouse worker $4 \%$

$\%$ other $5 \%$

Job status:

$\%$ full time $52 \%$

$\%$ part-time $43 \%$

$\%$ on call relief $6 \%$

(adapted from Table 7b p.15, Emlen, 1990).

When asked about the areas of stress in their life (see Table 2), more than half of the women reported some or a lot of stress in the area of child care. Most of the women also reported some or a lot of stress in the job category. 
TABLE II

DEPENDENT VARIABLE FREQUENCIES, BY PERCENT $(\mathrm{N}=825)$

Stress -percent who report

some or a lot:

Childcare stress

$61 \%$

Job stress

$72 \%$

Role Conflict -percent who report

difficulty in combining

work and family

$55 \%$

(adapted from Table 5b p.13, Emlen, 1990).

Table III provides the frequencies on the independent variables. Nearly half of the women said they were completely responsible for child care, while just over 20 percent said they were mostly responsible. Additionally, just over 20 percent said they shared it with their spouse. only 1 percent of women said their spouse was completely responsible for child care.

Regarding difficulty in managing child-care arrangements, Table III shows that forty-seven percent of women reported difficulty paying for child care.

Thirty percent of women said management practices made it difficult to handle child-care problems during work. While over 30 percent of women stated that they liked everything about their child-care arrangements, about onefifth said the cost was too high and that they were worried about their child's safety. Somewhat fewer also said that it 
was too far from home and that there are too many kids in the child-care setting. Over one-fourth of the women had concerns other than those listed.

TABLE III

INDEPENDENT VARIABLE FREQUENCIES, BY PERCENT

Job Support -percent who say management

$(N=722) \quad$ practices make it difficult

to handle child-care problems

during work

$30 \%$

Spousal support -who's responsible for

$(N=718)$ child care?

$\%$ employee completely

$\%$ employee mostly

$\%$ shared with spouse $22 \%$

$\%$ spouse mostly

\% spouse completely

Affordability -percent who report difficulty $(N=476) *$ paying for child care $47 \%$

Dissatisfaction with child-care arrangements

\begin{tabular}{llr}
\hline$(\mathrm{N}=720)$ & -percent who disliked \\
& characteristics about arrangements \\
& $\%$ like everything & \\
& $\%$ too far from home & $34 \%$ \\
& $\%$ cost too high & $13 \%$ \\
& $21 \%$ \\
& $\%$ dislike program & $3 \%$ \\
& $\%$ say too many kids & $3 \%$ \\
& $\%$ worried about safety & $13 \%$ \\
& $21 \%$ \\
& $\%$ too dirty & $1 \%$ \\
& & $26 \%$
\end{tabular}

(adapted from Table 25b p.33, Emlen, 1990).

* Excludes those who don't pay

Regarding child-care arrangements, many women reported having more than one type of care. For example, 50 percent 
of women who have children under age one had more than one arrangement. Of these, 54 percent said their spouse cared for the child in the home at least part of the time and 50 percent said the child was in family day care at least part of the time. Eighteen percent reported that the child was sometimes in a relative's home and 16 percent reported that the child was sometimes in a child-care center.

\section{FINDINGS ON THE HYPOTHESES}

\section{Hypothesis 1}

As job support increases, stress will decrease. A crosstabulation was calculated and the analysis indicated a moderate positive correlation between job support and childcare stress (Gamma $=.333$, Pearson's $r=.267, \mathrm{p}<.001$ ). Table IV illustrates this relationship. Evident among the women in this sample were ongoing struggles with taking care of child-care problems during work hours. Approximately thirty percent of the women reported that management practices made this area difficult to deal with (including the responses "somewhat difficult", "difficult", and "very difficult").

As job support increased, fewer women identified child care as a source of stress for them over the past four weeks. Although the overall correlation was weak, there was a strong increase in the percentage of women who reported a lot of child-care stress as job support decreases. 
TABLE IV

JOB SUPPORT AND CHILD-CARE STRESS

BY PERCENT

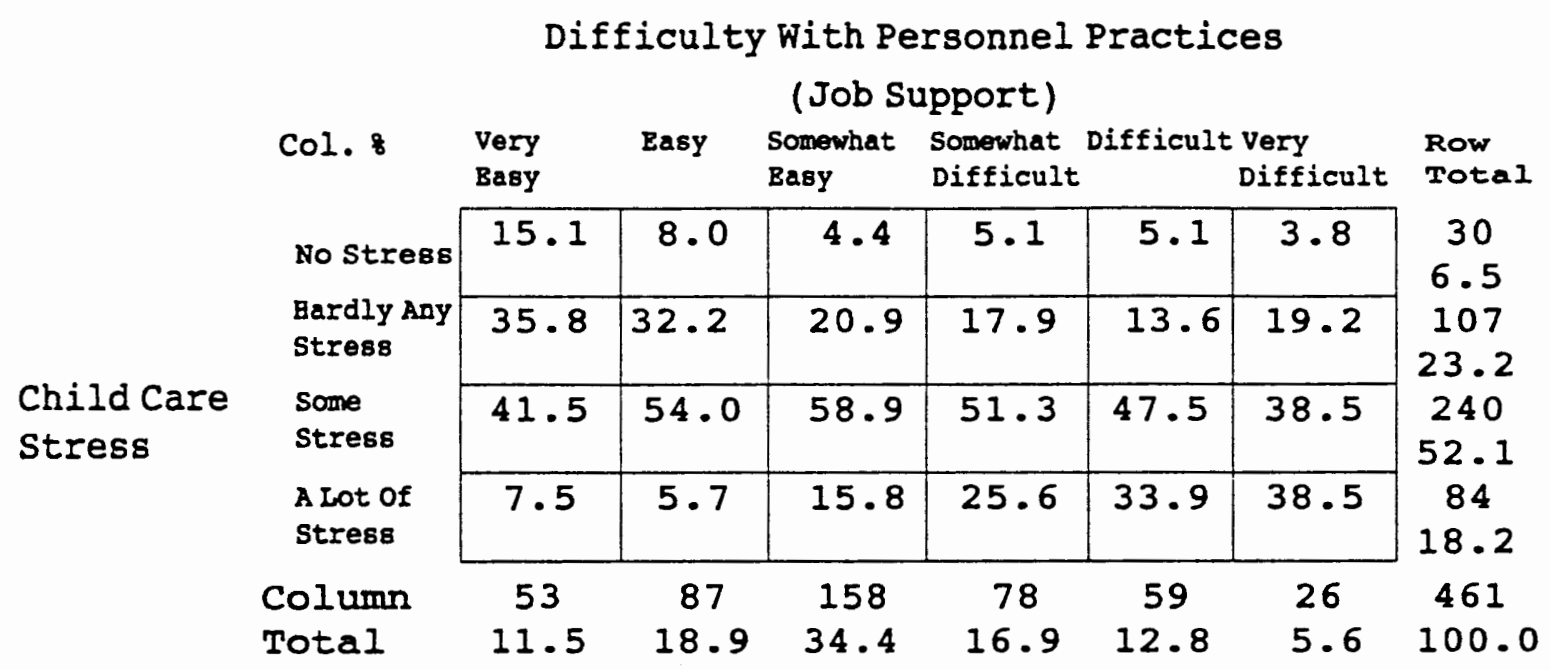

There was a weak positive correlation between lack of job support for child care and job stress (Gamma=.205, Pearson's $r=.170, p<.001)$. Table $V$ shows this relationship, which again goes in the expected direction: the more job support, the more the stress is reduced. However, the correlation between job support and child-care stress was stronger than that between job support and job stress.

As Table $V$ shows, approximately 33 percent of those who reported that they had a very difficult time with personnel practices reported "a lot" of job stress, while only 
approximately 3 percent of those who reported that their personnel practices made it very easy to take care of childcare problems at work also reported a lot of job stress.

\section{TABLE V}

JOB SUPPORT AND JOB STRESS BY PERCENT

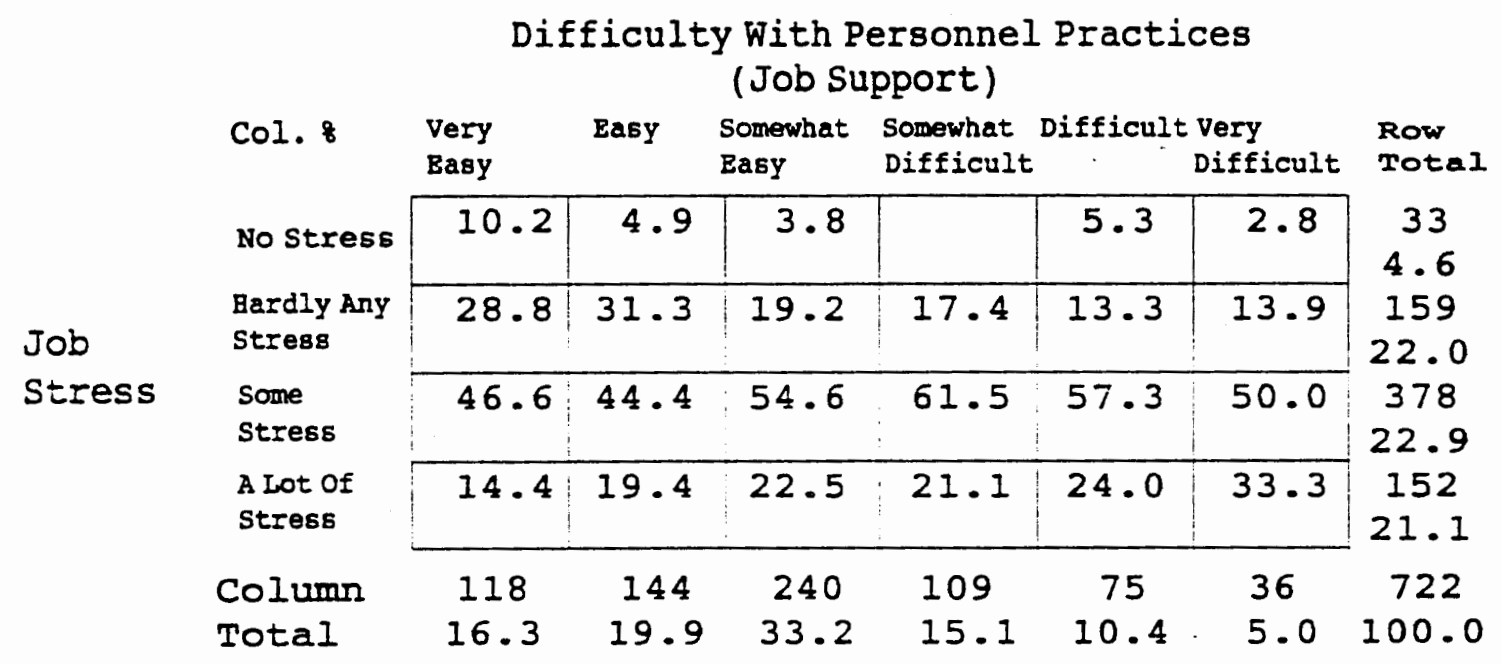

Hypothesis 2

As job support increases, role conflict will decrease. The results show a moderate positive correlation between lack of job support and role conflict (Gamma $=.300$, Pearson's $r=.264 \mathrm{p}<.001$ ). As Table VI illustrates, while only a small percent of women reported great difficulty in combining work 
and family, the percentage who did increased from 0 (most job support) to 11 percent (least job support).

TABLE VI

JOB SUPPORT AND ROLE CONFLICT

BY PERCENT

Difficulty With Personnel Practices

(Job Support)

\begin{tabular}{|c|c|c|c|c|c|c|c|c|}
\hline & Col. 8 & $\begin{array}{l}\text { Very } \\
\text { Basy }\end{array}$ & Easy & $\begin{array}{l}\text { Somewhat } \\
\text { Easy }\end{array}$ & $\begin{array}{l}\text { Somewhat } \\
\text { Difficult }\end{array}$ & Difficult & Difficult & $\begin{array}{l}\text { Row } \\
\text { Total }\end{array}$ \\
\hline \multirow[b]{3}{*}{$\begin{array}{l}\text { Difficulty } \\
\text { in Combining }\end{array}$} & $\begin{array}{l}\text { Very } \\
\text { Basy }\end{array}$ & 6.0 & 4.2 & 1.7 & & 2.7 & & \multirow{3}{*}{$\begin{array}{l}19 \\
2.6 \\
59 \\
8.2 \\
229\end{array}$} \\
\hline & Basy & 19.7 & 8.4 & 5.4 & 2.8 & 6.7 & 8.3 & \\
\hline & $\begin{array}{l}\text { Somewhat } \\
\text { Basy }\end{array}$ & 38.5 & 38.5 & 31.7 & 27.5 & 17.3 & 27.8 & \\
\hline $\begin{array}{l}\text { Work and } \\
\text { Family }\end{array}$ & $\begin{array}{l}\text { Somewhat } \\
\text { Difficuit }\end{array}$ & 26.5 & 36.4 & 47.5 & 48.6 & 40.0 & 30.6 & $\begin{array}{l}291 \\
40.4\end{array}$ \\
\hline $\begin{array}{l}\text { (Role } \\
\text { Conflics) }\end{array}$ & Difficul= & 9.4 & 9.1 & 10.4 & 17.4 & 28.0 & 22.2 & $\begin{array}{c}97 \\
13.5\end{array}$ \\
\hline & $\begin{array}{l}\text { Very } \\
\text { DifEicult }\end{array}$ & & 3.5 & 3.3 & 3.7 & 5.3 & 11.1 & $\begin{array}{l}25 \\
3.5\end{array}$ \\
\hline & $\begin{array}{l}\text { nمulol } \\
\text { :otal }\end{array}$ & $\begin{array}{l}117 \\
16.3\end{array}$ & $\begin{array}{r}143 \\
19.9\end{array}$ & $\begin{array}{l}240 \\
33.3\end{array}$ & $\begin{array}{c}109 \\
15.1\end{array}$ & $\begin{array}{l}75 \\
10.4\end{array}$ & $\begin{array}{l}36 \\
5.0\end{array}$ & $\begin{array}{l}720 \\
100.0\end{array}$ \\
\hline
\end{tabular}

\section{Hypothesis 3}

As spousal help increases, stress will decrease. Table VII presents the crosstabulation that shows the Pearson's $r$ between spousal help and child-care stress is close to zero $(-.036$, N.S). The Gamma is -.059 and is also nonsignificant. 
In testing the hypothesis on spousal support, single women were omitted. Additionally, because there were such small numbers of women who indicated that their spouse "mostly" or "completely" handled the child-care arrangements, only the respondents who stated that they were "completely responsible," "mostly responsible," or "shared" the responsibility with their spouses were considered. The relationship between spousal help and job stress was not statistically significant.

The interpretation of these results are confusing as there might be more stress as spousal support increases if a woman is concerned about her spouse's abilities in this area. It is notable that $53 \%$ of the women with a child under age one were dissatisfied with in-home care by their spouse, slightly higher than the $50 \%$ who were dissatisfied with their family day care arrangement. Yet, of those women who reported " a lot of stress," none said that their spouse was either mostly or completely responsible for child care (Data not presented here). While this hypothesis focused on childcare stress when women take on all or most of the responsibility, it may be that other forms of sharing the responsibility for child care have stressful aspects that this research didn't anticipate. For example, a woman may be questioning her own ability to arrange for safe and secure child care, or she may be questioning her husband's ability to do the same. Either of these situations could also cause 
stress.

\author{
TABLE VII \\ SPOUSAL SUPPORT AND CHILD-CARE STRESS \\ BY PERCENT
}

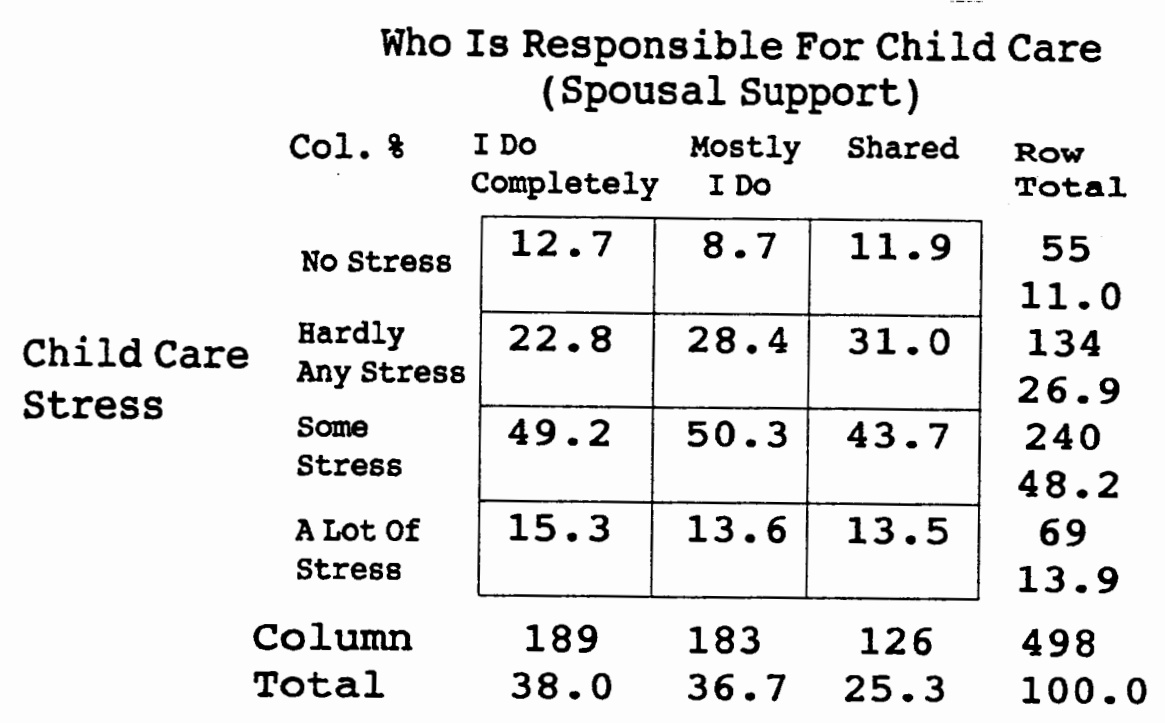

Hypothesis 4

As spousal help increases, role conflict will decrease. The analysis showed no statistical significance between spousal help with child care and role conflict (Pearson's $r$ $=-.048$, N.S., Gamma $=-.065$, N.S.). Table VIII presents the interesting distribution, which shows that about $3 / 4$ of the women were completely or mostly responsible for child care. 
Again, this analysis was conducted using only married women.

TABLE VIII

SPOUSAL SUPPORT AND ROLE CONFLICT

BY PERCENT

Who Is Responsible For Child Care

(Spousal Support)

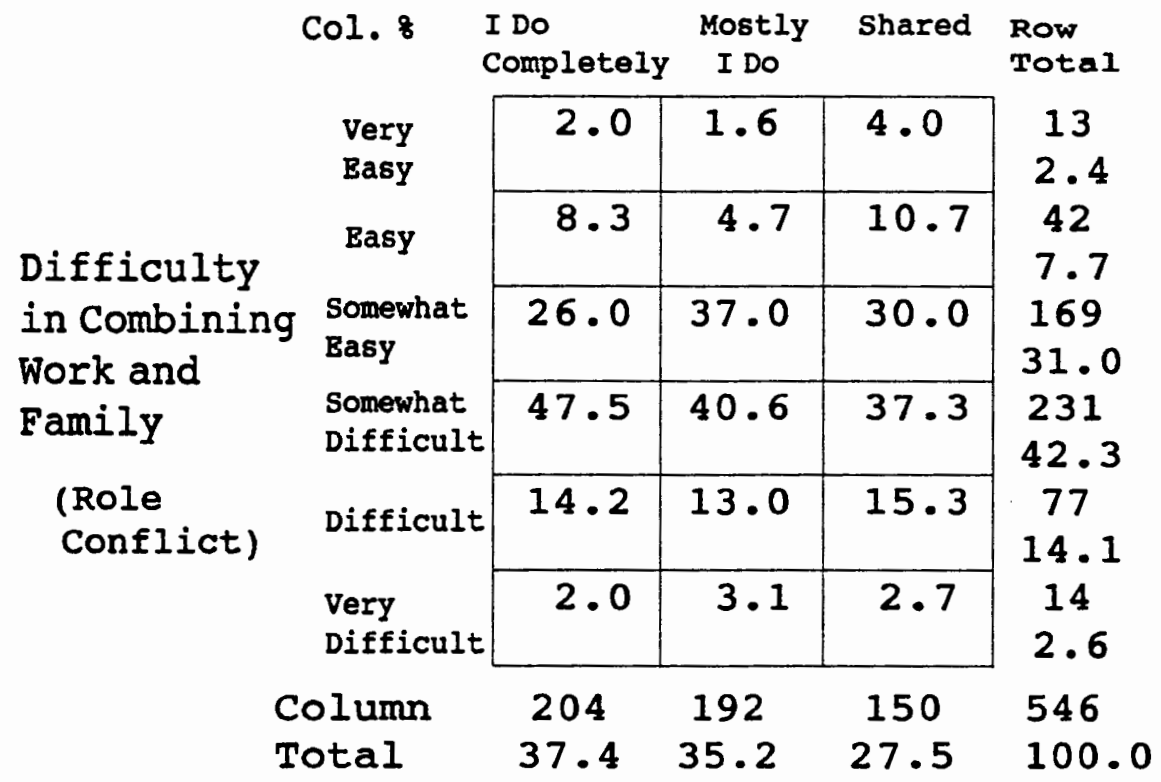

Hypothesis 5

As affordability of child care increases, stress will

decrease. There is a moderate relationship between

affordability and child-care stress (Gamma=.347, Pearson's

$r=.287, p<.001)$. Table IX illustrates the results of this

cross-tabulation. The results suggest that many women do 
have difficulty in paying for child care ( $47 \%$ of the women reported some to great difficulty in paying for child care). Among those women who reported the least affordability ("very difficult" to pay), one reported that they experienced "no stress", whereas $46 \%$ reported that they experienced "a lot of stress".

TABLE IX

\section{AFFORDABILITY AND CHILD CARE-STRESS}

BY PERCENT

\section{Difficulty Paying For Child Care}

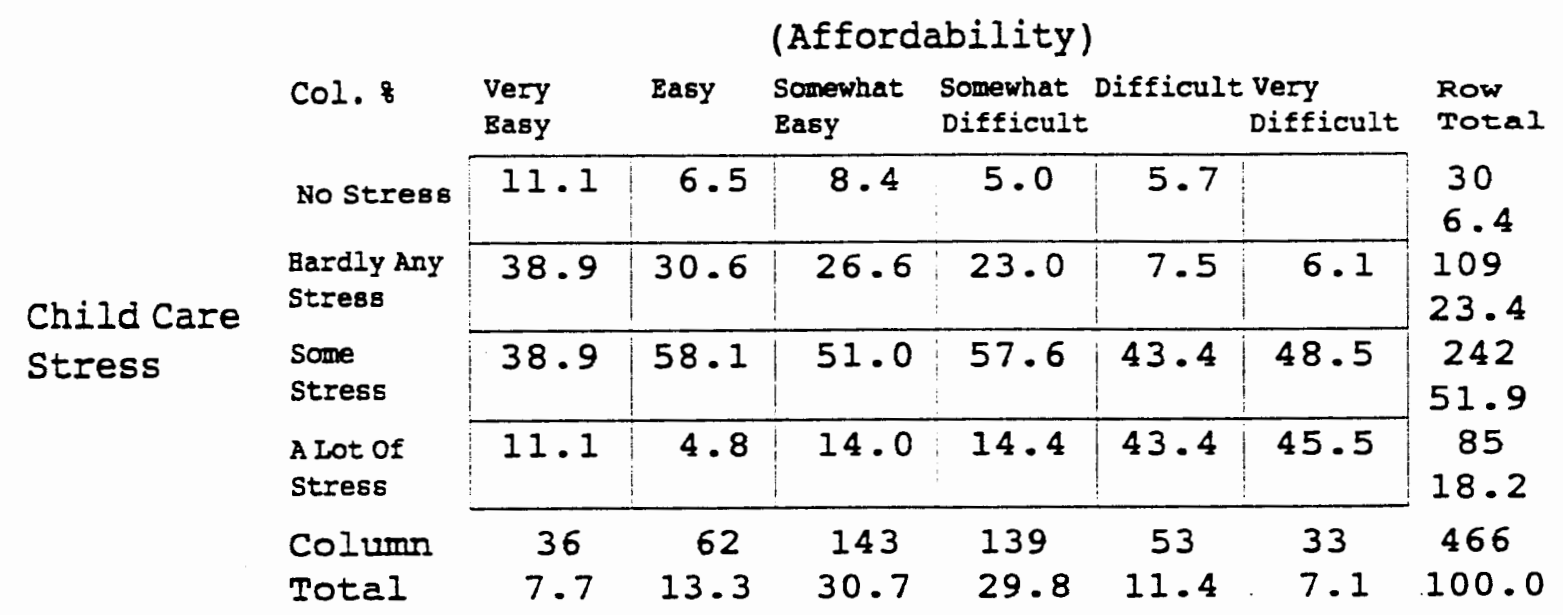

There were 259 women who didn't pay for child care and they were eliminated from this analysis (this accounted for $33.4 \%$ of the respondents).

There was no statistically significant relationship 
between difficulty in paying for child-care and job stress.

Hypothesis 6

As affordability of child care increases, role conflict will decrease. As above, 259 women reported they didn't pay for child care and they were eliminated from this particular analysis. The results indicated a moderate relationship between these two variables (Gamma=.245, Pearson's $r=.210$, $\mathrm{p}<.001$ ). As Table $\mathrm{x}$ shows, the easier it is to pay for child care, the easier it is to combine work and family (i.e. role conflict decreases).

TABLE X

AFFORDABILITY AND ROLE CONFLICT

BY PERCENT

Difficulty Paying For Child Care

(Affordability)

\begin{tabular}{|c|c|c|c|c|c|c|c|c|}
\hline & \multirow{2}{*}{$\begin{array}{l}\text { Col, } 8 \\
\text { Very } \\
\text { Basy }\end{array}$} & $\begin{array}{l}\text { Very } \\
\text { Easy }\end{array}$ & \multirow[t]{2}{*}{ Easy } & \multirow[t]{2}{*}{$\begin{array}{l}\text { Somewhat } \\
\text { Basy }\end{array}$} & \multirow{2}{*}{$\frac{\begin{array}{l}\text { Somewhat } \\
\text { Difficult }\end{array}}{1.4}$} & Difficult & $\begin{array}{l}\text { Very } \\
\text { Difficult }\end{array}$ & \multirow{2}{*}{$\begin{array}{c}\text { Row } \\
\text { Total } \\
6 \\
1.3\end{array}$} \\
\hline & & 5.6 & & & & & 5.7 & \\
\hline & Basy & 11.1 & 6.3 & 5.6 & 9.4 & 7.0 & 2.9 & $\begin{array}{l}34 \\
7.2\end{array}$ \\
\hline $\begin{array}{l}\text { Difficulty } \\
\text { in Combining }\end{array}$ & $\begin{array}{l}\text { Somewhat } \\
\text { Basy }\end{array}$ & 27.8 & 39.1 & 42.4 & 21.6 & 17.5 & 8.6 & $\begin{array}{c}139 \\
29.3\end{array}$ \\
\hline $\begin{array}{l}\text { Work and } \\
\text { Family }\end{array}$ & $\begin{array}{l}\text { Somewinat } \\
\text { Difficult }\end{array}$ & 33.3 & 45.3 & 41.7 & 52.5 & 33.3 & 40.0 & $\begin{array}{c}207 \\
43.6\end{array}$ \\
\hline $\begin{array}{l}\text { (Role } \\
\text { Conflict) }\end{array}$ & Difficult & 16.7 & 9.4 & 6.9 & 11.5 & 36.8 & 31.4 & $\begin{array}{c}70 \\
14.7\end{array}$ \\
\hline & $\begin{array}{l}\text { Very } \\
\text { Difficult }\end{array}$ & 5.6 & & 3.5 & 3.6 & 5.3 & 11.4 & $\begin{array}{l}19 \\
4.0\end{array}$ \\
\hline $\begin{array}{l}C \\
T\end{array}$ & $\begin{array}{l}\text { olumn } \\
\text { otal }\end{array}$ & $\begin{array}{l}36 \\
7.6\end{array}$ & $\begin{array}{l}64 \\
13.5\end{array}$ & $\begin{array}{c}144 \\
30.3\end{array}$ & $\begin{array}{c}139 \\
29.3\end{array}$ & $\begin{array}{l}57 \\
12.0\end{array}$ & $\begin{array}{r}35 \\
7.4\end{array}$ & $\begin{array}{c}475 \\
100.0\end{array}$ \\
\hline
\end{tabular}


Hypothesis 7

As satisfaction with child-care arrangements increases, stress will decrease. of those who indicated at least one problem with their child-care arrangements (indicated by checking at least one item of dissatisfaction), there was a moderate correlation between dissatisfaction and child-care stress (Gamma $=.439$, Pearson's $r=.340, p<.001$ ). Table XI shows the cross-tabulation in this analysis.

of those respondents who checked three or more dissatisfactions, there were none who reported no childcare stress and less than 4 percent who reported hardly any stress. Only about 9 percent of those who checked no dissatisfaction reported a lot of stress. As outlined in the beginning of this chapter, women are dissatisfied with their child-care arrangements for a variety of reasons (refer to Table III). Thirty four percent of the respondents liked everything about their child-care arrangements, and they were excluded from this cross-tabulation. ${ }^{3}$ Twenty-six percent of the respondents checked "other" when asked about what in particular they were dissatisfied with regarding their child-care arrangements, instead of one of the specific items listed such as "worried about safety". These respondents were also excluded from this particular

3 out of the total number of respondents who liked everything about their child care arrangements, only 7.6 percent reported "a lot" of child care stress, while 42 percent reported "some stress" and about 50 percent indicated they had "hardly any" to "none". 
analysis.

TABLE XI

DISSATISFACTION WITH CHILD-CARE ARRANGEMENTS

AND CHILD-CARE STRESS

BY PERCENT

Dissatisfaction With Child Care Arrangements (Number of Items Respondents Checked)

\begin{tabular}{|c|c|c|c|c|c|c|c|c|}
\hline & Col. 8 & .00 & 1.00 & 2.00 & 3.00 & 4.00 & 5.00 & $\begin{array}{l}\text { Row } \\
\text { Total }\end{array}$ \\
\hline & No stress & 11.0 & 3.3 & 1.6 & & & & 30 \\
\hline & $\begin{array}{l}\text { Eardly Any } \\
\text { Stress }\end{array}$ & 29.8 & 21.9 & 15.6 & 3.8 & & & $\begin{array}{r}109 \\
23.4\end{array}$ \\
\hline $\begin{array}{l}\text { Child Care } \\
\text { Stress }\end{array}$ & $\begin{array}{l}\text { Some } \\
\text { Stress }\end{array}$ & 49.5 & 55.0 & 62.5 & 30.8 & 60.0 & & $\begin{array}{r}242 \\
51.9\end{array}$ \\
\hline & $\begin{array}{l}\text { A Lot of } \\
\text { Stress }\end{array}$ & 9.6 & 19.9 & 20.3 & 65.4 & 40.0 & 100.0 & $\begin{array}{c}85 \\
18.2\end{array}$ \\
\hline & $\begin{array}{l}\text { Column } \\
\text { Total }\end{array}$ & $\begin{array}{c}218 \\
46.8\end{array}$ & $\begin{array}{l}151 \\
32.4\end{array}$ & $\begin{array}{c}64 \\
13.7\end{array}$ & $\begin{array}{c}26 \\
5.6\end{array}$ & $\begin{array}{c}5 \\
1.1\end{array}$ & $\begin{array}{c}2 \\
0.4\end{array}$ & $\begin{array}{c}466 \\
100.0\end{array}$ \\
\hline
\end{tabular}

There was no statistical correlation between satisfaction with child-care arrangements and job stress (Pearson's $r=.010$, N.S., Gamma $=.023$, N.S.).

Hypothesis 8

As satisfaction with child care increases, role conflict will decrease. The results show a weak correlation 
between satisfaction with child-care arrangements and role conflict (Gamma $=.211$, Pearson's $r=.177, p<.001$ ). The more items the respondent checks that she is dissatisfied with, the more role conflict she experiences. Table XII illustrates this analysis.

\section{TABLE XII}

DISSATISFACTION WITH CHILD-CARE ARRANGEMENTS

AND ROLE CONFLICT

BY PERCENT

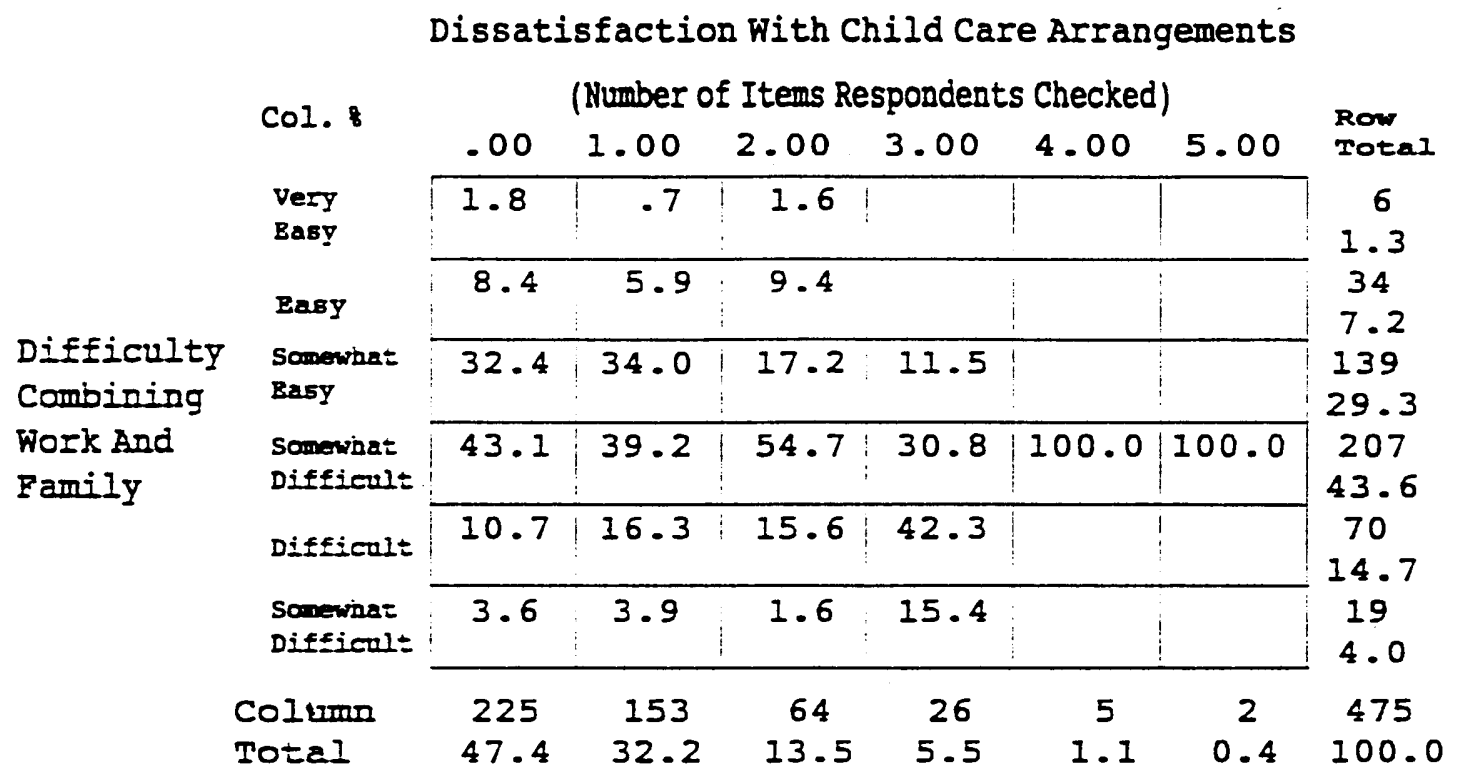


Table XIII provides a summary of the statistical results and the significance levels.

TABLE XIII

SIGNIFICANCE OF RELATIONSHIPS BETWEEN INDEPENDENT VARIABLES AND DEPENDENT VARIABLES

\begin{tabular}{|c|c|c|c|c|}
\hline Hypotheses & Gamma & Pearson's $r$ & $p$ & Decision \\
\hline Job support X CC Stress & .333 & .267 & $<.001$ & Confirmed \\
\hline Job support X Job Stress & .205 & .170 & $<.001$ & Confirmed \\
\hline Job support $X$ Role Conflict & .300 & .264 & $<.001$ & Confirmed \\
\hline Spousal help X CC Stress & & & N.S. & Not Conf. \\
\hline Spousal help $x$ Job Stress & & & N.S. & Not Conf. \\
\hline Spousal help $x$ Role Conflict & & & N.S. & Not Conf. \\
\hline Affordability X CC Stress & .347 & .287 & $<.001$ & Confirmed \\
\hline Affordability $x$ Job Stress & & & N.S. & Not Conf. \\
\hline Affordability $x$ Role Conflict & .245 & .210 & $<.001$ & Confirmed \\
\hline Satisfaction X CC Stress & .439 & .340 & $<.001$ & Confirmed \\
\hline Satisfaction $\mathrm{x}$ Job Stress & & & N.S. & Not Conf. \\
\hline Satisfaction $\mathrm{X}$ Role Conflict & .211 & .177 & $<.001$ & Confirmed \\
\hline
\end{tabular}




\section{CHAPTER V}

\section{DISCUSSION}

The results of this study show relationships between job support, spousal help, affordability of child care and satisfaction with child-care arrangements and the dependent variable, stress regarding child care. The only variable significantly related to job stress was job support ( where there was a weak relationship). Additionally, there were significant relationships between job support, affordability of child care, and satisfaction with child-care arrangements and the dependent variable, role conflict.

It became apparent that studying a woman's child-care arrangements, and the potential effects they might have on her, was more complicated than first anticipated. As mentioned earlier, for women with children under age one, 50 percent had more than one kind of child-care arrangement, and this number jumped to 72 percent when the age of the child is two. One can imagine the chaos when a family has three or more children to arrange for. This particular survey also asked women how satisfied they were with the arrangement for each child (this particular question was not analyzed in this study). The multiplicity of arrangements caused great difficulty in trying to analyze which 
arrangement caused more stress or less stress. For example, a mother may have her child in family day care for twenty hours a week, at a relative's three hours a week, in an afterschool program five hours a week, and in self-care ten hours a week. How she comes to answer a question about overall stress relating to child-care can be confusing. The most recent U.S. Bureau of census report on childcare arrangements (Fall 1988) divides arrangements into primary care and secondary care; moreover school is considered a child-care arrangement. The census report (1988) showed that for the primary arrangement, 28 percent of the mothers responded that their child under age five was cared for by someone in their own home, while 36 percent were cared for in someone else's home and 25 percent were in an organized day care facility. However, use of the primarysecondary split may obscure the existence of complex arrangements. Kamerman (1980) has documented that employed parents develop their own intricate child-care system with a number of child-care arrangements for each child that may change daily or seasonally. This can be further confounded by the women who work part-time, who comprised 48 percent of the present sample. It could be, for example, that parttime women experience more stress because they not only have to arrange for child care, but they also have more time actually caring for the children and are more vulnerable to mental distress from children-related pressures. There is 
some evidence that non-employed women experience more children-related pressures than working women. For example, Gove and Geerken (1977) found in their study that although working mothers devoted a great deal of time to caring for their children, even at the expense of sleep and free time, they reported more positive feelings toward their children than did non-employed mothers. Non-employed mothers described parenthood as more restricting, burdensome, and demanding than did employed mothers.

Overall, the findings from this study are consistent with earlier works which emphasize the importance of having reliable child care. Hughes and Galinsky (1988) found that having a supervisor who was insensitive to work and family roles was the variable most predictive of stress for both women and men, but that for men only, it was associated with more frequent psychosomatic symptoms and greater work-family interference. Another finding in their study was that a reliable system of child care was extremely important in promoting the positive mental and physical health of mothers. The more frequently the child care broke down, the more likely the mother was to have higher levels of workfamily interference. Pleck, staines and Lang (1980) also found that problems with child care were related to overall work-family interference.

Besides difficulties in analyzing the stress of multiple child-care arrangements, some researchers have 
struggled with the operationalization and measurement of role conflict (see Verbrugge, 1986). Specific, objective measures of role conflict are difficult to develop because of the numerous dimensions of role conflict. One might try and measure role conflict by including items such as number of days missed at work due to a sick child, difficulties resulting from conflicting demands of work and family or friends, constraints on professional travel imposed by family demands, and so forth. A factor analysis would be one approach to conceptual development here.

Verbrugge(1986) indicates that objective and subjective measures of role conflict might produce divergent findings. She notes that subjective indicators will typically be more highly correlated with psychological well-being variables than will objective ones. Because of this it is preferable that measures of overload or conflict be consistently objective or subjective or that they be capable of separate analyses.

One finding that is difficult to explain is the lack of association between job stress and the dependent variables. one explanation why job stress was not strongly associated could be that the independent variables had more to do with child care than the job. If more of the questions had asked about the job, the analyses may have yielded stronger relationships. 
SCARCITY AND EXPANSION HYPOTHESES

As mentioned earlier, both the scarcity hypothesis and the expansion hypothesis are incomplete because they focus on the quantity of roles rather than on their nature and quality. Also neglected are considerations of gender. Neither one recognizes, for example, that being both parent and paid worker is experienced differently for men and women. The finding in this study that about 75 percent of the women were completely or mostly responsible for child care indicates that this is one difference for men and women. As discussed earlier, for men the worker role often satisfies both work and family obligations simultaneously. Moreover, the expansion hypothesis doesn't take into account that many women have jobs that don't offer the same privileges as male-dominated professions. Again, in this study, a significant number of women had jobs in the clerical and nursing categories, which typically do not allow for much freedom and flexibility on the job. The scarcity hypothesis cannot account for evidence that occupying the paid worker role may reduce, rather than increase, the stress of women who are also wives and mothers. 


\section{CORPORATE CONCERN ABOUT CHILD CARE}

Because of its apparent instability in this country, the issue of child care is becoming increasingly important to business and industry. Work-family problems are increasingly seen as the result of the unevenness of social change: families are changing faster than other societal institutions. Much of the research in this area focuses specifically on how employers can help families and how such help might be cost-effective by reducing turnover and absenteeism (Friedman, 1991; Emlen and Koren, 1984; Emlen and Koren, 1990). One study (Emlen and Koren, 1984) revealed that child care was clearly a major source of absenteeism, adding that sex differences in absenteeism seemed to be the result of women being primarily responsible for managing child care. Neal and associates (1993) reported that "resource variables that significantly predicted two out of three absenteeism measures included work schedule flexibility, ease in finding and continuing child care, and satisfaction with child care" (p.177). Additionally, ease of finding and continuing child care were associated with fewer instances of arriving late, leaving early and being interrupted at work (Neal et al., 1993). The present study also indicated that women were often dissatisfied with their arrangements for a variety of reasons, and this impacted their stress levels. Other areas that companies are concerned about are productivity and turnover. A survey of 
the Adolph Coors Company (1987) found more than one-third (36 percent) of its employees reporting a decline in productivity due to the child-care problems of co-workers. The same study concluded:
Based on self-disclosed survey results, employees with children miss two to three days every six months due to sick children. If 47 percent of our Coors employees have children needing child care and 47 percent of these employees miss 2 to 3 days of work because of sick children, a metro-Denver employee population of 8,000 employees, means approximately 3,530 to 5,300 work days are missed every six months. At an average wage of $\$ 120 /$ day, sick child absenteeism costs coors $\$ 847,200$ to $\$ 1,272,000$ a year. Add the cost of replacement employees and reduced productivity and sick child cost is even higher (p. 17).

There are several programs that companies can offer their employees that can help alleviate stress and role conflict (Hughes and Galinsky 1988):

1) Resource and Referral - to assist parents in locating quality child care.

2) Support for Community Child Care - Company gives financial support to existing child-care programs. 3) On or near-site child care - Companies subsidize and manage work-site centers alone or as part of a consortium of companies. Some contract with child-care professionals to develop a child-care center and pay all or part of the start-up costs and/or a portion of operating costs. 4) Sick Child care/ Travel care - Facilities or special arrangements are offered for care of sick children. In a review of six studies that surveyed perceptions 
of the users of employer-sponsored child-care centers, Galinsky, Friedman, and Hernandez (1991) noted that employees tended to believe that morale was the most likely benefit, although many reported that their absenteeism had declined and their productivity improved because of the child-care center. The present study showed that job support, in general, was associated with lower child-care stress, job stress, and role conflict.

Flextime is another area of job support that is widely studied in the area of corporate research (Friedman, 1991; Galinsky, Friedman, and Hernandez, 1991). Although as mentioned earlier it may not be sufficient, flextime may help some women. It can help employees with family responsibilities by allowing an employee to arrange more time with the family and by reducing work-family conflict by eliminating or reducing scheduling problems (Friedman, 1991)

\section{AFFORDABILITY}

The findings in this study are consistent with earlier work that shows that affordability of child care is a factor in women's stress as it relates to child care. Even though child-care workers are among the lowest paid of all workers, child care is often the third to fourth most costly item in the family's budget (Friedman, 1985). Furthermore, child care is commonly perceived as a woman's expense that must be 
justified by comparing her income with the costs of her employment, such as child care, transportation, lunch money, clothes, etc. In fact, an estimated 1.1 million mothers ages 21 - 29 said they were out of the labor force in 1986 because of child-care problems, and the proportion of poor mothers reporting this was twice as high as their non-poor counterparts (Cattan,1991). Much of the research on the affordability of child care is on the users of it; hence there are limitations on the conclusions because the women who have dropped out of the labor force, or never entered it, are excluded.

\section{SPOUSAL SUPPORT}

The finding of a relationship between spousal support and stress and role conflict is similar to other research. Several studies have found that the greater the husbands' participation in domestic activities, the better the wives' mental health (Kessler and McRae, 1982; Pleck, 1985). In particular, Kessler and Mccrae (1982), using data from national probability samples, found that husbands' help with child care, increased the beneficial impact of employment on the women's health. There are several causal interpretations that might underlie this relationship. It may be that egalitarianism in marriage is negatively associated with wives' stress levels. The relationship might also suggest that husband's domestic participation alleviates some of the 
role overload their wives might otherwise experience, thus leading to a decrease in wives' stress levels.

\section{FEMINIST WORK ON BALANCING WORK AND FAMILY}

As discussed earlier, some of the research performed on work-family conflict has been from a feminist perspective. The results of the present study are consistent with the view that "greedy institutions" claim a high percentage of women's time and that employed mothers do put in a "second shift". They are also consistent with other research that identifies "supports", whether they are from the job, family, or community, as being important in reducing employed mothers'stress.

One feminist argument is that supports must be institutionalized in order to enable employed women to manage job and family responsibilities.

POSITIVE ASPECTS OF JUGGLING FAMILY AND WORK

In the areas of maternal employment and child-care research, much of the attention has been paid to the welfare of the children as the parents work. Some portion of this research has concluded that maternal employment is harmful to children ( Willner, 1965 and Belsky, 1986). Other recent research, though, actually proclaims benefits to children in day care, such as the capacity to love and trust more than one adult and the expertise of the child-care workers 
$($ Scarr, 1984$)$.

still other research points out benefits to working mothers such as positive self-images and advantages associated with multiple roles (Crosby, 1991). Multiple roles may free a person from some of the role obligations attached to particular statuses. One study (Gove and zeiss, 1987) showed that divorced parents with joint custody both performed parental roles but, by sharing these roles with ex-spouses, they had more time to spend on work and other activities. Thus, the notion that more roles create stress is not necessarily correct. Multiple roles create permission as well as pressure to compartmentalize, identified by Goode (1960) as one of the mechanisms through which which people reduce role strain. By compartmentalizing their roles women can escape from the Iimitless expectations of the "greedy institution" (Coser, 1975) of the family, in which their role obligations seem to expand to fill the time available. This study showed only a weak relationship, where any, between job stress and the independent variables. This may mean that some women are able to compartmentalize their child-care stress and their job-related stress. This does contradict the research that shows that child-care problems interefere with productivity on the job, though. 
CONCLUDING REMARKS

What is clear from the expansive amount of research on the effects of maternal employment on mothers and their children is that the workplace is beginning to recognize their role in responding to the work-family needs of their workers. Companies are competing for a shrinking number of workers, many of whom are female. The needs of these workers will have an impact on whether or not they enter the labor force and for whom they will work.

Women with children have accounted for most of the recent increases in the female work force. According to the U.S. Bureau of the census (1989), the labor force participation rate for women 18 - 44 years old with children under age one, was 51 percent. In 1976, the percentage was only 31 percent. Additionally, two-thirds of mothers of children under 18 hold jobs outside the home (U.S. Bureau of the Census, 1989).

Some companies are taking these numbers seriously and are devising programs to accomodate working mothers, but the change is slow. Corporate policy can do much to reduce the tension between the demands of the workplace and families. The research described in this thesis shows that working women do experience stress and role conflict. Other research has gone further, to show that this in turn affects members of their family as well as their employer (Friedman, 1991). More research in this area is warranted, particularly 
on a larger scale. Due to the increase in the number of young women in the labor force, government needs to expand its involvement. National level research could help inform policy. Presently, the government is tackling the difficult issue of health care reform, and there's reason to believe that child-care reform could be upcoming in the near future. It can be shown that these problems can be cost-effective through the reduction of absenteeism and turnover and an increase in productivity, as well as improving the health and well-being of families. creating family-friendly programs and policies should be a high priority for corporations and government alike. 


\section{REFERENCES}

Barnett, R.C and Baruch, G.K. 1985. "Women's Involvement in Multiple Roles and Psychological Distress". Journal of Personality and Social Psychology, 49 (1), 135-145.

Baruch, G.K. , Barnett R.C., and Rivers, C. 1985. New Patterns of Love and Work for Today's Woman. New York: Signet.

Baruch, G.K. and Barnett, R.C. 1986. "Consequences of Father's Participation in Family and work: Parent's Role Strain and Well-being". Journal of Personality and Social Psychology, 51,983-992.

Belsky, J. 1986. "Infant Day Care: A Cause for Concern?" Zero to Three, sept.

Bohen, H. and Viveros-Long, A. 1981. Balancing Work and Family Life. Philadelphia, Temple University Press.

Burden, D. S. and Googins, B.K. 1987. Boston University's Balancing Life and Home study, Boston, MA: Boston University School of Social Work.

Cattan, P. 1991. "Child-care Problems: An Obstacle to Work". Monthly Labor Review, $114: 10,3-9$.

Cherlin, A. 1988. The Changing American Family and Public Policy. New York: Sage.

Coors Child Care Needs Assessment: Proposal and Recommendations Denver, Colorado: Adolph Coors Company, 1987.

Coser, R.I. and Rokoff, J. 1971. "Women in the Occupational World: Social Disruption and Conflict." Social Problems, 18, 535-554.

Coser, L. 1974. Greedy Institutions: Patterns of Undivided Commitment. New York: Signet.

Couter, A.C. et. al. 1987. Processes Underlying Father Involvement in Dual-earner and single- earner

Families", Developmental Psychology, 23, 341-440. 
Coverman, S. 1989. "Role Overload, Role Conflict and stress: Addressing the Consequences of Multiple Role Demands. "Social Forces, 67:4, 965-982.

Cowan, R.S. 1983. More Work for Mother. New York: Basic
Books.

Crosby, F. 1984. "Job Satisfaction and Domestic Life." Pp. 168-193 in Management of Work and Personal Life, edited by M.D. Lee and R.N. Kanugo. New York: Praeger.

1987. Spouse, Parent, Worker: On gender and Multiple Roles. New Havens: Yale University Press.

Emlen, A.C. 1990. Employee Profiles Lane County Dependent Care Survey Portland, OR: Arthur Emlen and Associates, Inc., and Portland State University, Regional Research Institute for Human Services.

Emlen, A.C. and Koren, P.E. 1984. Hard to find and Difficult to Manage: The Effects of Childcare on the Workplace. Portland, OR: Arthur Emlen and Associates, Inc., and Portland State University, Regional Research Institute for Human Services.

Emlen, A.C. and Koren, P.E. 1990. Lane County Dependent Care Survey: Summary of findings and conclusions. Portland, OR: Arthur Emlen and Associates, Inc., and Portland State University, Regional Research Institute for Human Services.

Epstein, c. 1983 (April). "The New Total Woman." Working Woman.

Filene, P. 1974. Him, Her, Self: Sex Roles in Modern America. New York: Harcourt, Brace Jovanovich.

Friedan, B. 1963. The Feminine Mystique. New York: Dell Publishing.

Friedan, B. 1981. The second stage New York: Summit Books.

Friedman, D. 1991 Linking Work-Family Issues to the Bottom Line. New York:The Conference Board Report \#962.

Galinsky, E. 1986. "Family Life and Corporate Policy," in In Support of Families, edited by M. Yorman and $\mathrm{T}$. Brazelton. Boston, MA: Harvard University Press.

Galinsky, E. Friedman, D.E., and Hernandez, C.A. 1991. The Corporate Reference Guide to Work-Family programs. New York: Families and Work Institute. 
Goode, W.J. 1960. "A theory of role strain". American Sociological Review, 25, 483-496.

Gove, W.R., and Geerken, M.R. 1977. "The Effect of Children and Employment on the Mental Health of Married Men and Women". Social Forces, 56, 66-76.

Gove, W.R. and Zeiss, C. 1987. "Multiple roles and happiness." In Spouse, Parent and Worker: On gender and multiple roles, edited by Faye Crosby. New Havens: Yale University Press.

Harrell, J. and Ridley, C. 1975. "Substitute Child Care, Maternal Employment, and the Quality of Mother-child Interaction." Journal of Marriage and the Family, 37 ,
556-564.

Hewlett, S.A. 1991. When the Bough Breaks. New York: Basic Books.

Hochschild, A. 1989. The Second Shift. New York: Avon Books.

Hock, H., Gnezda, T., and McBride, S. 1984. "Mothers of Infants: Attitudes Toward Employment and Motherhood Following Birth of First Child", Journal of Marriage and the Family, 46, 425-31.

Hoffman,F. 1985. "Serving the Needs of Children: Child Care in the Voluntary Sector". In Gary Tobin (Ed.), Planning and Social service Delivery in the Voluntary sector, Westport, CT: Greenwood Press.

Hughes, D. and Galinsky, E. 1988. Balancing Work and Family Life: Research and Corporate Application. New York: Bank street College of Education.

Kahn, R.I., Wolfe, D.M., Quinn, R.P., Snoek, J.D., and Rosenthal, R.A. 1964. Organizational stress: studies in Role Conflict and Ambiguity. New York: Wiley.

Kamerman, S.B. 1980. Parenting in an unresponsive society. New York: The Free Press.

Kanter, R.M. 1977. Work and Family in the United States: A Critical Review and Agenda for Research and Policy. New York: Russel Sage.

Keith, P. and Schafer, R.B. 1980. "Role Strain and Depression in Two-job Families." Family Relations, 29, $483-488$. 
Kessler, R. and Mccrae, J. 1982. "The Effects of Wives' Employment on the Mental Health of Men and Women." American Sociological Review, 47: 216-227.

Kessler-Harris, A. 1981. Out to Work: A History of WageEarning women in the United States. New York: Oxford

Komarovsky, M. 1962. Blue-collar Marriage. New York: Random
House.

Kopelman, R.E., Greenhaus, J.H. and Connolly, T.F. 1983. "A Model of Work, Family and Interrole Conflict: A Construct Validation study." organizational Behavior and Human Performance, 32:198-215.

LaVee, Y., McCubbin, H., and Patterson, J. 1985. "The Double ABCX Model of Family stress and Adaptation: An Empirical Test by Analysis of Structural Equations with Latent Variables." Journal of Marriage and the Family
$47: 811-825$.

Long, J. and Porter, K. 1984. "Multiple Roles of Midlife Women: A Case for New Directions in Theory, Research, and Policy." Pp. 109-160 in Between Youth and Old Age: Women in the Middle Years, edited by G. Baruch and $J$. Brooks-Gunn. New York: Plenum.

Marks, S.R. 1977. "Multiple Roles and Role Strain: : Some Notes on Human Energy, Time and Commitment". American Sociological Review, 41, 921-936.

Mccubbin, H. et al. 1980. "Family stress and Coping: A Decade Review." Journal of Marriage and the Family, 42 : 855-871.

Mischel, H.N. and Fuhr, R. 1992. "Maternal Employment: It's Psychological Effects on Children and Families". in Feminism, Children, and the New Families, edited by $S$. Dornsbusch and $M$. Strober. New York: The Guilford Press.

Neal, M.B., Chapman, N.J., Ingersoll-Dayton, B., Emlen, A.C. 1993 Balancing Work and Caregiving for Children. Adults, and Elders. Newbury Park: Sage.

Nye, F.I., and Hoffman, I.W. (eds.). 1963. The Employed Mother in America, New York: Rand McNally.

Nye, F.I., and Hoffman, I.W. (eds.). 1974. Working Mothers : An Evaluative Review of the consequences for Wife, Husband, and Child. San Francisco: Jossey-Bass. 
Pahl, J.M. and R.E. 1971. Managers and Their Wives. London: Penguin.

Phillips, D. 1989. "Future Directions and Need for Child Care in the United States." In Caring for Children, edited by J.S. Lande, S. Starr, and N. Gunzenhauser. Hillsdale, N.J.: Ehrlbaum.

Piotrowsky, C.S. 1979. Work and the Family system. New York: Free Press.

Piotrowski, C.S. and Crits-Christoph, P. 1981. "Women's Jobs and Family Adjustment." Journal of Family Issues, 2, 126-147.

Piotrowski, C.S. and Katz, M.H. 1983. "Work Experience and Family Relations Among Working-class and Lower Middleclass Families." In Research in the Interweave of

Social Roles, Vol. 3 Families and Jobs, edited by H.Z. Lopata and J.H. Pleck. Greenwich, CT: JAI Press.

Pleck, J.H. 1985. "The Consequences of Role Overload." In Working Wives, Working Husbands, edited by J.H. Pleck. New York: Sage.

Pleck, J.H., Staines, G.L. and Lang, L. 1980. "Conflicts Between Work and Family", Monthly Labor Review, 103 (3), 29-32.

Renshaw, J.R. 1976. "An Exploration of the Dynamics of the Overlapping Worlds of Work and Family." Family Process, $35,143-165$.

Repetti, R.L. 1987. "Linkages Between Family and Work Roles", in Family processes and Problems, edited by $S$. Oskamp. Newbury Park, CA: sage.

Rubin, I. 1976. Worlds of Pain. New York: Basic Books.

Scanzoni, J. 1978. Sex Roles, Women's Work, and Marital Conflict. Lexington, MA: D.C. Heath.

Scarr, S. 1984. Mother Care/ other Care New York: Basic Books.

Sieber, S.D. 1974. "Toward a Theory of Role Accumulation". American Sociological Review, $39,567-578$.

Skold, K. 1992. 'The Interests of Feminists and Children in Child Care." Pp. 113-136 in Feminism, Children and the New Families, edited by S.M. Dornbusch and M. Strober. New York: The Guilford Press. 
Slater, P. 1963. "On Social Regression". American Sociological Review, 28, 339-364.

Stromberg, A.H. and Harkess, S. Women Working. Mountain, CA: Mayfield Publishing.

Thoits, P.A. 1983. "Multiple Identities and Psychological Well-being: A Reformulation and Test of the Social Isolation Hypothesis. American Sociological Review, 48 , 174-187.

-----. 1986. "Multiple Identities: Examining Gender and Marital status Differences in Distress." American Sociological Review, 51: 259-272.

U.S. Bureau of the Census, "Changes in American Family Life", Current Population Reports Series P-23, No. 163, August, 1989, p.17.

Verbrugge, L. 1986. "Role Burdens and Physical Health of Women and Men." Women and Health, 7:262-283.

Verbrugge, V. and Madans, J.H. 1985. "Social Roles and Health Trends of American Women". Millbank Memorial Fund Quarterly, 63:691-735.

Willner, M. 1965. "Day Care: A Reassessment", Child Welfare, $44: 126$. 